\title{
Chapter 11 \\ Calcium Mobilization via Intracellular \\ Ion Channels, Store Organization and Mitochondria in Smooth Muscle
}

\author{
John G. McCarron, Susan Chalmers, Calum Wilson, and Mairi E. Sandison
}

\begin{abstract}
In smooth muscle, $\mathrm{Ca}^{2+}$ release from the internal store into the cytoplasm occurs via inositol trisphosphate $\left(\mathrm{IP}_{3} \mathrm{R}\right)$ and ryanodine receptors $(\mathrm{RyR})$. The internal $\mathrm{Ca}^{2+}$ stores containing $\mathrm{IP}_{3} \mathrm{R}$ and $\mathrm{RyR}$ may be arranged as multiple separate compartments with various $\mathrm{IP}_{3} \mathrm{R}$ and RyR arrangements, or there may be a single structure containing both receptors. The existence of multiple stores is proposed to explain several physiological responses which include the progression of $\mathrm{Ca}^{2+}$ waves, graded $\mathrm{Ca}^{2+}$ release from the store and various local responses and sensitivities. We suggest that, rather than multiple stores, a single luminally-continuous store exists in which $\mathrm{Ca}^{2+}$ is in free diffusional equilibrium throughout. Regulation of $\mathrm{Ca}^{2+}$ release via $\mathrm{IP}_{3} \mathrm{R}$ and $\mathrm{RyR}$ by the local $\mathrm{Ca}^{2+}$ concentration within the stores explains the apparent existence of multiple stores and physiological processes such as graded $\mathrm{Ca}^{2+}$ release and $\mathrm{Ca}^{2+}$ waves. Close positioning of $\mathrm{IP}_{3} \mathrm{R}$ on the store with mitochondria or with receptors on the plasma membrane creates ' $\mathrm{IP}_{3}$ junctions' to generate local responses on the luminally-continuous store.
\end{abstract}

Keywords Smooth muscle $\bullet$ Calcium signalling $\bullet$ Calcium stores $\bullet$ IP3 receptors $\bullet$ Ryanodine receptors $\bullet$ Quantal calcium release $\bullet$ Mitochondria

\section{Introduction}

$\mathrm{Ca}^{2+}$ regulates several smooth muscle functions including contraction, proliferation and the changes in muscle performance that accompanies disease [1]. The characteristics of the $\mathrm{Ca}^{2+}$ signal (e.g. the amplitude, duration, frequency and location) determine the nature of the biological response. A major $\mathrm{Ca}^{2+}$ source in smooth muscle is

The original version of this chapter was revised. An erratum to this chapter can be found at DOI 10.1007/978-3-319-29635-7_19

J.G. McCarron $(\varangle) \bullet$ S. Chalmers $\bullet$ C. Wilson • M.E. Sandison

Strathclyde Institute of Pharmacy and Biomedical Sciences, University of Strathclyde,

SIPBS Building, 161 Cathedral Street, Glasgow G4 0RE, UK

e-mail: john.mccarron@strath.ac.uk 


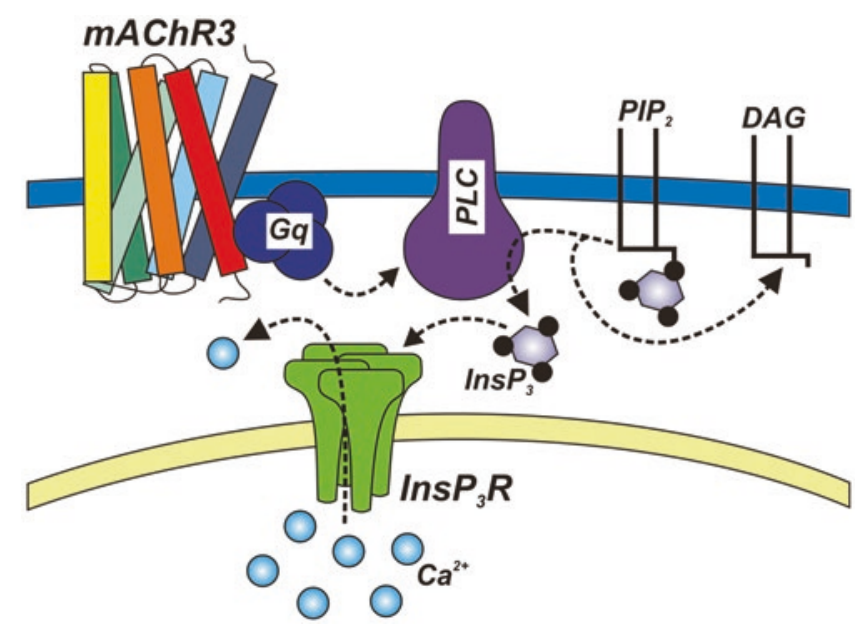

Fig. 11.1 Receptor activation and generation of $\mathrm{IP}_{3}$ and $\mathrm{Ca}^{2+}$ release. Muscarinic receptors $(\mathrm{mAChR} 3)$, phospholipase $\mathrm{C}(\mathrm{PLC})$ and $\mathrm{IP}_{3} \mathrm{R}$ may be co-localized to create junctions in which $\mathrm{IP}_{3}$ acts as a highly localized signal by being rapidly delivered to $\mathrm{IP}_{3} \mathrm{R}$. PIP2, phosphatidylinositol 4,5-bisphosphate; DAG diacylglycerol

an internal storage compartment which accumulates $\mathrm{Ca}^{2+}$ via sarco/endoplasmic reticulum $\mathrm{Ca}^{2+}$-ATPases (SERCA). $\mathrm{Ca}^{2+}$ is released from the store into the cytoplasm via the ligand-gated channel/receptor complexes, the inositol trisphosphate $\left(\mathrm{IP}_{3} \mathrm{R}\right)$ and ryanodine receptors. Release of $\mathrm{Ca}^{2+}$ via $\mathrm{IP}_{3} \mathrm{R}$ is activated by $\mathrm{IP}_{3}$ generated in response to many G-protein or tyrosine kinase-linked receptor activators including drugs (Fig. 11.1). RyR may be activated pharmacologically (e.g. caffeine), by $\mathrm{Ca}^{2+}$ influx from outside the cell in the process of $\mathrm{Ca}^{2+}$-induced $\mathrm{Ca}^{2+}$ release (CICR), or when the stores's $\mathrm{Ca}^{2+}$ content exceeds normal physiological values, i.e. in 'store overload' [2-6]. Activation of either receptor allows diffusion of $\mathrm{Ca}^{2+}$ from the store to increase the cytoplasmic $\mathrm{Ca}^{2+}$ concentration $\left(\left[\mathrm{Ca}^{2+}\right]_{\mathrm{c}}\right)$ from the resting value of $\sim 100 \mathrm{nM}$ to $\sim 1 \mu \mathrm{M}$ for many seconds throughout the cell and briefly (e.g. $100 \mathrm{~ms}$ ) to much higher values (e.g. $50 \mu \mathrm{M}$ ) in small parts of the cytoplasm.

\section{Physiological Functions Proposed to Be Explained by the Structure of the Store}

The amplitude and duration of the $\mathrm{Ca}^{2+}$ signal depends on the quantity of $\mathrm{Ca}^{2+}$ available for release, which is determined in large part by the structural arrangement of the store. The store appears as an interconnected network of tubules [7] with a single lumen in which $\mathrm{Ca}^{2+}$ is in free diffusional equilibrium throughout (Fig. 11.2) [e.g. 8, 9]. However, considerable controversy persists about the stores structural and functional continuity or discontinuity. Rather than a store with a single lumen, multiple separate smaller $\mathrm{Ca}^{2+}$ storage units may exist (Fig. 11.2) [e.g. 7, 10-12]. Although the structure is unresolved, the arrangement of the store is proposed to account for several characteristics of $\mathrm{Ca}^{2+}$ 

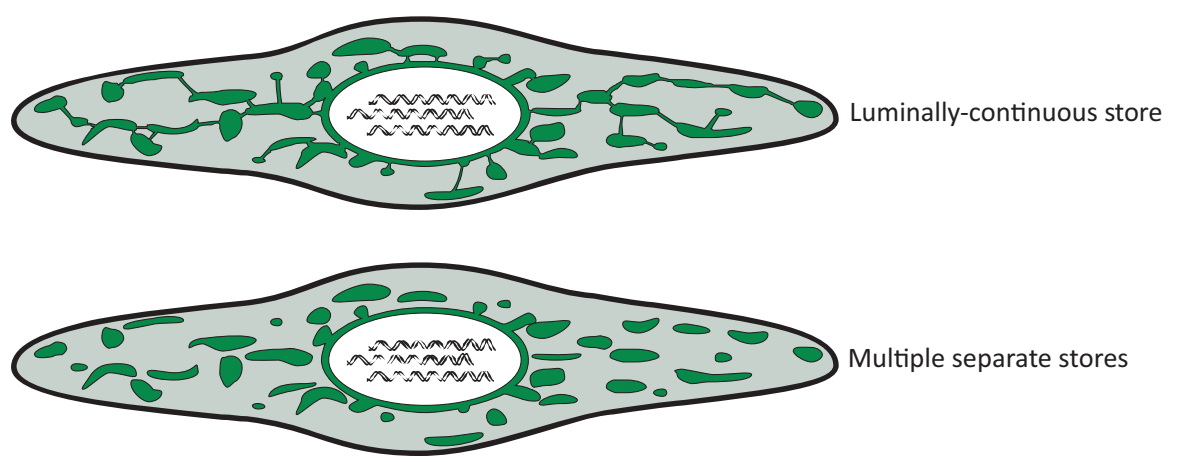

Fig. 11.2 Arrangement of the store. The store may be a single luminally-continuous structure with $\mathrm{Ca}^{2+}$ in free diffusional equilibrium throughout (top) or a series of multiple separate elements (bottom)

signals, such as the graded concentration-dependence of $\mathrm{IP}_{3}$-mediated $\mathrm{Ca}^{2+}$ release, the variation in sensitivity in different parts of the cell to generate local responses and the progression of $\mathrm{Ca}^{2+}$ signals through the cell. For example, while $\mathrm{Ca}^{2+}$ entry via voltagedependent $\mathrm{Ca}^{2+}$ channels generates quite uniform rises in $\mathrm{Ca}^{2+}$ (Fig. 11.3; $[13,14]$ ), $\mathrm{Ca}^{2+}$ release from internal stores may generate complex patterns, such as travelling spatial gradients of $\mathrm{Ca}^{2+}$ (' $\mathrm{Ca}^{2+}$ waves'; Fig. 11.3). For $\mathrm{Ca}^{2+}$ waves to progress through the cell, sequential activation of $\mathrm{IP}_{3} \mathrm{R}$ [13], by $\mathrm{Ca}^{2+}$ itself, occur in a repeating positive feedback CICR-like process $[15,16]$, i.e. $\mathrm{Ca}^{2+}$ release from one $\mathrm{IP}_{3} \mathrm{R}$ activates neighbouring receptors to progress the wave. An explanation put forward to explain wave movement, rather than there being a persistent $\mathrm{Ca}^{2+}$ release at one site on the cell, is that store is arranged as several stores along the length of the cell, each with a limited amount of $\mathrm{Ca}^{2+}$. Each store is activated and depleted in turn (Fig. 11.4a).

A discontinuous structure of the store has also been proposed to explain the graded $\mathrm{IP}_{3}$ concentration-dependent $\mathrm{Ca}^{2+}$ release process $[17,18]$. Low concentrations of $\mathrm{IP}_{3}$ release only part of the overall available $\mathrm{Ca}^{2+}$ content of the store $[17,19-22]$. As the $\mathrm{IP}_{3}$ concentration increases, a further release of $\mathrm{Ca}^{2+}$ occurs [reviewed 23]. Such a graded release seems incompatible with the positive feedback CICR-like facility at $\mathrm{IP}_{3} \mathrm{R}$ [24], which would be anticipated to fully deplete the store when activated. To explain graded $\mathrm{Ca}^{2+}$ release, the store has been proposed to assemble in multiple separate units, each endowed with a finite $\mathrm{Ca}^{2+}$ storage capacity and sensitivity to $\mathrm{IP}_{3}$ (Fig. 11.4b). At any given concentration of $\mathrm{IP}_{3}$ only some stores will be activated to release $\mathrm{Ca}^{2+}[17,18,25]$ (Fig. 11.4b). This same feature of the store may also explain the reported variations in sensitivity different parts of the cell to $\operatorname{IP}_{3}[19,26,27]$.

\section{Structure of the $\mathrm{Ca}^{2+}$ Stores}

There are several different RyR and $\mathrm{IP}_{3} \mathrm{R}$ arrangements which may exist on each of the proposed separate stores to explain the various experimental observations. Indeed, the $\mathrm{Ca}^{2+}$ stores have been classified on the arrangement of $\mathrm{IP}_{3} \mathrm{R}$ and $\mathrm{RyR}$ and proposals for one, two, or more, stores with a variety of complex receptor 


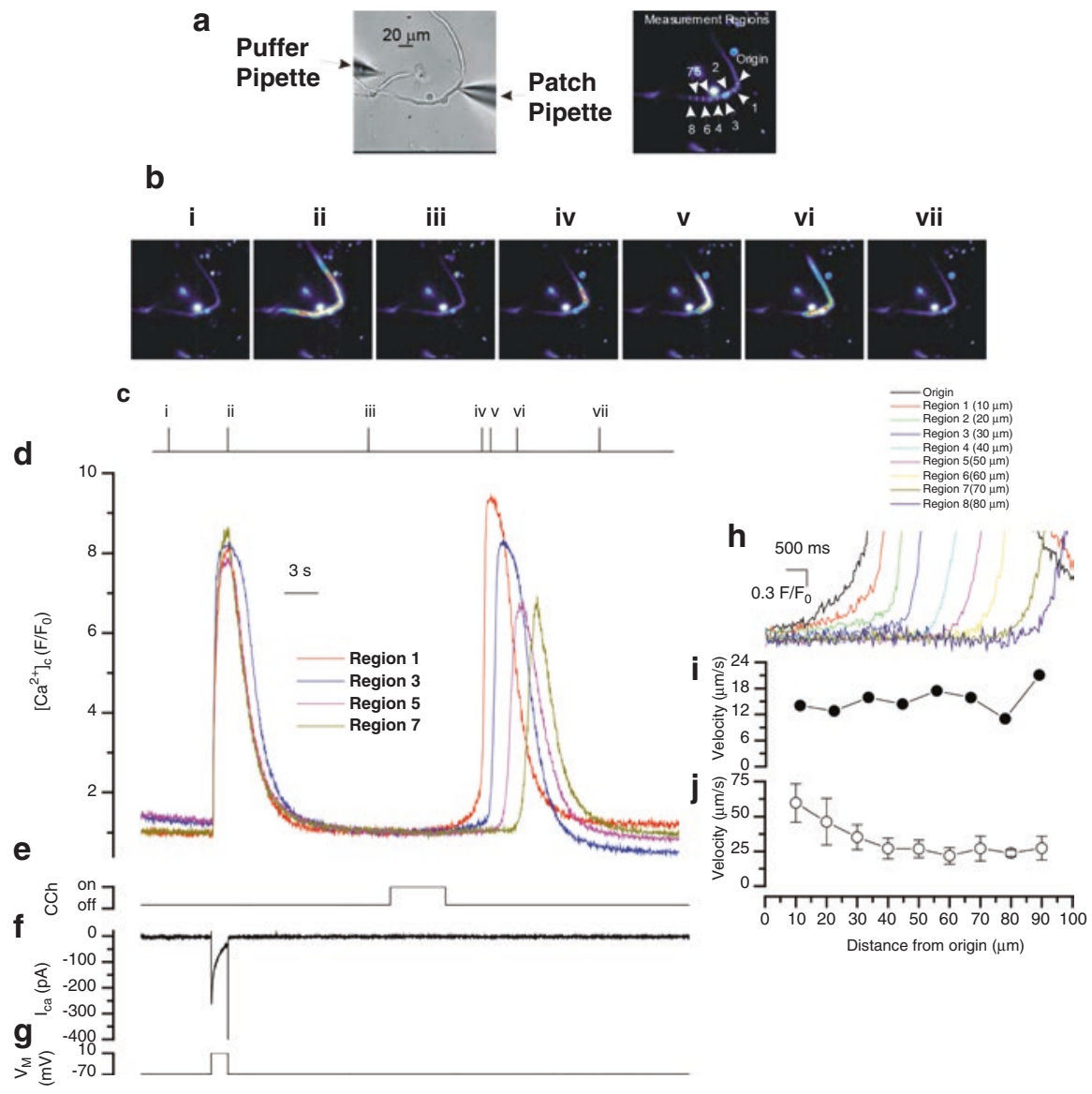

Fig. 11.3 Depolarization and $\mathrm{IP}_{3}$-evoked increases in $\left[\mathrm{Ca}^{2+}\right]_{\mathrm{c}}$. Depolarization $(-70 \mathrm{mV}$ to $+10 \mathrm{mV}$; g), activated a voltage-dependent $\mathrm{Ca}^{2+}$ current $\left(\mathrm{I}_{\mathrm{Ca}} ; \mathbf{f}\right)$ to evoke a relatively uniform rise in $\left[\mathrm{Ca}^{2+}\right]_{\mathrm{c}}$ $(\mathbf{b}, \mathbf{d})$. In contrast, $\left[\mathrm{Ca}^{2+}\right]_{\mathrm{c}}$ increases in response to and $\mathrm{IP}_{3}$-generating agonist began in one part of the cell and progressed from that site $(\mathbf{b}, \mathbf{d}$ and expanded time base $\mathbf{h})$. The $\left[\mathrm{Ca}^{2+}\right]_{\mathrm{c}}$ images $(\mathbf{b})$ are derived from the time points indicated by the corresponding numerals in $\mathbf{c}$. $\left[\mathrm{Ca}^{2+}\right]_{\mathrm{c}}$ changes in $\mathbf{b}$ are represented by colour; blue low and red/white high $\left[\mathrm{Ca}^{2+}\right]_{\mathrm{c}}$. Changes in the fluorescence ratio with time (d, h) are derived from 1 pixel lines ('origin' and regions 1-8 in a, right panel; drawn at a 3 pixel width to facilitate visualization). (a) Left panel shows a bright field image of the cell; see also whole cell electrode ( $r i g h t$ side) and puffer pipette containing agonist (left side). The velocity of wave progression is shown in $\mathbf{i}$ for the data presented in $(\mathbf{d}, \mathbf{h})$. Summarized velocity data is presented $(\mathbf{j} \mathrm{n}=5)$. From McCarron et al. 2010 [13] with permission

arrangements have been made (Fig. 11.5). There may be multiple stores each containing both $\mathrm{IP}_{3} \mathrm{R}$ and RyR [28-32], or there may be stores which contain only RyR and separate stores only $\mathrm{IP}_{3} \mathrm{R}[12,28,32-34]$ (e.g. basilar mesenteric or pulmonary arteries; Fig. 11.5i, ii). In other studies, there may be $\mathrm{Ca}^{2+}$ stores containing $\mathrm{IP}_{3} \mathrm{R}$ and RyR together on some stores along with other separate stores in the same cell with either $\mathrm{IP}_{3} \mathrm{R}$ alone (e.g. pulmonary artery and aorta [29, 35]; Fig. 11.5iii) or RyR 


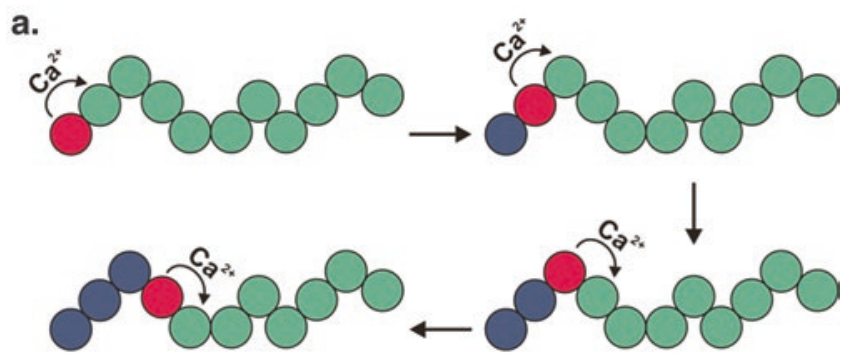

b.

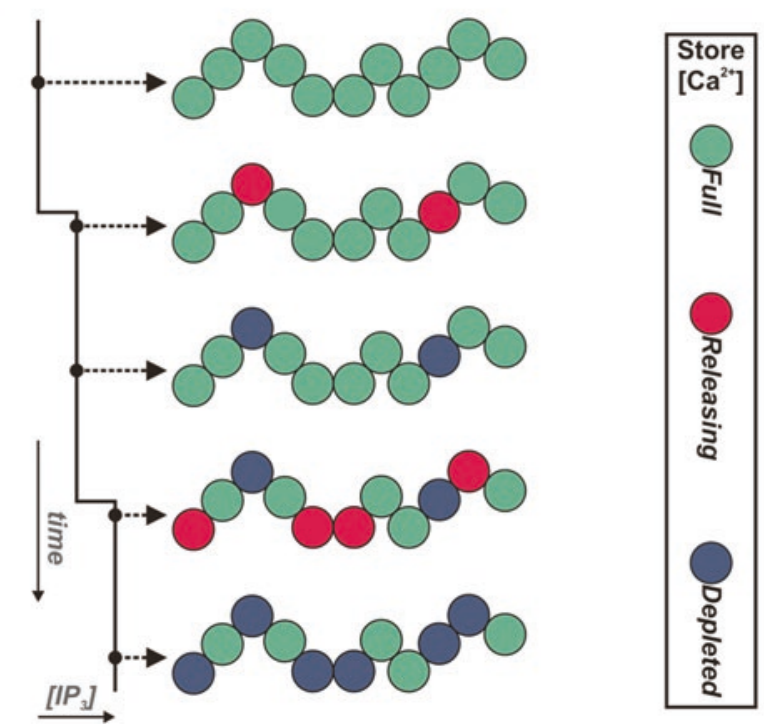

Fig. 11.4 Wave progression and store arrangement. (a) The store may function as a series of discontinuous compartments that are activated and depleted in turn to explain wave progression. (b) Separate stores with various sensitivities to $\mathrm{IP}_{3}$ are activated and depleted as the $\mathrm{IP}_{3}$ concentration (left-side) increases

alone (e.g. mesenteric artery [30]; Fig. 11.5iv). Stores have also been differentiated by their sensitivity to the SERCA pump inhibitors cyclopiazonic acid (CPA) and thapsigargin. In A7r5 cells (a cell line derived from thoracic aorta tissue) there are stores containing RyR that are insensitive to thapsigargin and separate stores in the same cells (also with RyR) that are sensitive to thapsigargin [12]. In an alternative proposal for store arrangement in A7r5 cells, a thapsigargin-insensitive store with $\mathrm{IP}_{3} \mathrm{R}$ but not RyR may exist [36]. In murine bladder smooth muscle, three types of $\mathrm{Ca}^{2+}$ store are proposed: two sensitive to thapsigargin, one with $\mathrm{IP}_{3} \mathrm{R}$ and one without, and a third store insensitive to $\mathrm{IP}_{3}$ and thapsigargin [37]. In tracheal myocytes three types of $\mathrm{Ca}^{2+}$ stores are proposed which were refilled by different pathways. $\mathrm{Ca}^{2+}$ influx through voltage-dependent $\mathrm{Ca}^{2+}$ channels and CPA sensitive pumps refilled $80 \%$ of the $\mathrm{IP}_{3} \mathrm{R}$-containing stores. The remaining $20 \%$ were not refilled by CPA-sensitive pumps or $\mathrm{Ca}^{2+}$ influx through voltage-dependent $\mathrm{Ca}^{2+}$ channels and 


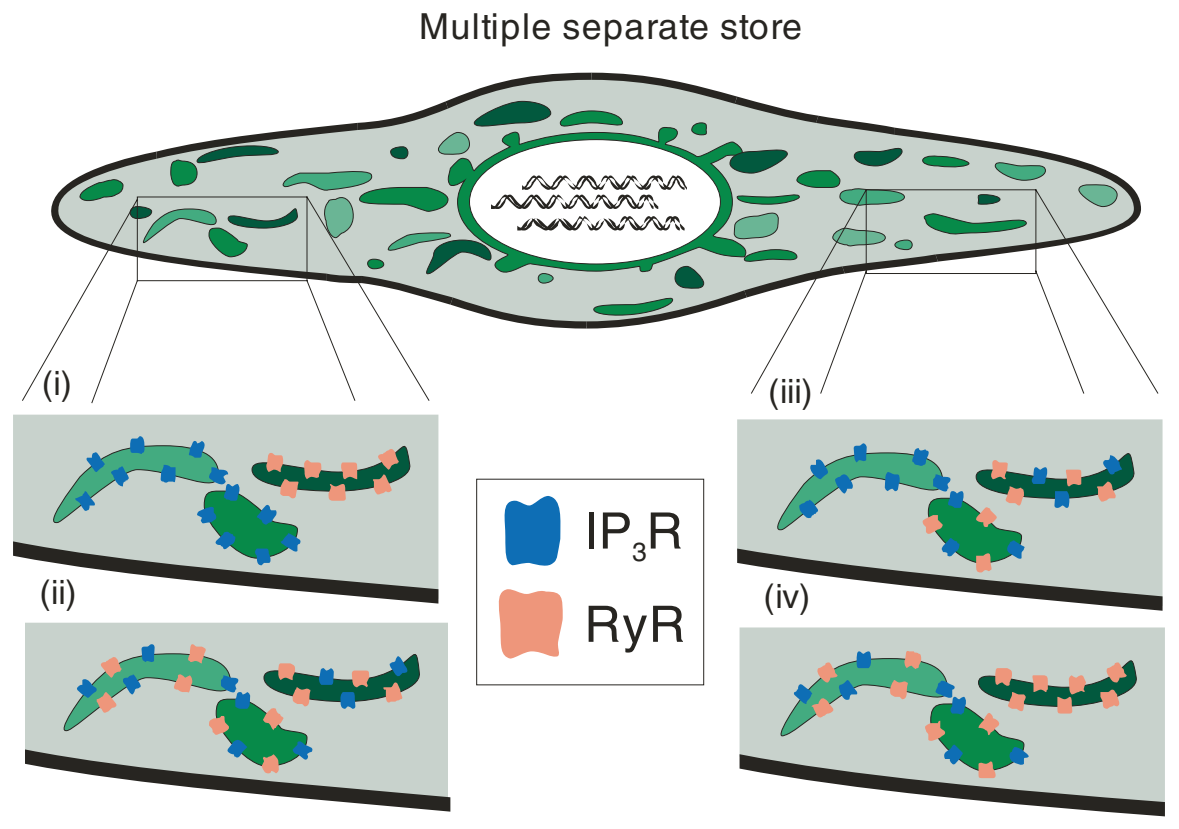

Fig. 11.5 Arrangement of RyR and $\mathrm{IP}_{3} \mathrm{R}$ on the store(s). There may be store with RyR (blue) alone or $\mathrm{IP}_{3} \mathrm{R}$ (red) alone (i), or stores with both receptors (ii) or a combination of the two (iii, iv). Although the cartoon shows the different proposed store receptor arrangements in the same cell, the proposed stores have been described for different cell types

neither was the RyR-containing store. Instead, thapsigargin depleted the CPA/ voltage-dependent $\mathrm{Ca}^{2+}$ channels insensitive $\mathrm{IP}_{3} \mathrm{R}$ store fully and the RyR store by more than $50 \%$ [38]. These differences in refilling mechanisms of the stores are proposed to demonstrate pharmacologically distinct $\mathrm{Ca}^{2+}$ stores which play an important role in the generation of $\mathrm{Ca}^{2+}$ signals in airway smooth muscle cells [38].

Thus, data from various functional studies suggest there may be structural discontinuities in the store and that different types of receptor arrangements on those stores exist. Proposals for stores which contain only $\mathrm{IP}_{3} \mathrm{R}$ or RyR exist as do proposals for stores with RyR and $\mathrm{IP}_{3} \mathrm{R}$ together and in combination with additional separate stores in the same cells containing only either $\mathrm{IP}_{3} \mathrm{R}$ or RyR. The questions arise, why is such a diversity of stores and receptor arrangement required and do functional experiments unambiguously reveal structural discontinuities in the store?

\section{Methods Used to Investigate Stores May Create the Appearance of Multiple Stores}

It could be the case that the experimental conditions used to investigate the stores may contribute to the diversity of proposals on arrangement. In native cells, methods for studying $\mathrm{Ca}^{2+}$ store subcompartments are limited. The main experimental 
approach is to define the structural organisation of the $\mathrm{Ca}^{2+}$ stores from functional $\left(\mathrm{Ca}^{2+}\right.$ response) data. To do this, the store is depleted typically via one receptor (RyR or $\mathrm{IP}_{3} \mathrm{R}$ ) by repeated activation with a single concentration of either $\mathrm{IP}_{3}$ or caffeine under conditions which prevent store refilling with $\mathrm{Ca}^{2+}$. After depletion via one receptor (e.g. RyR), whether or not $\mathrm{Ca}^{2+}$ is available to be released via the other receptor $\left(\mathrm{e} . \mathrm{g} . \mathrm{IP}_{3} \mathrm{R}\right)$ is then determined. If depletion via one receptor abolishes $\mathrm{Ca}^{2+}$ release from the other, the receptors are suggested to be co-localized on a single store and access a common $\mathrm{Ca}^{2+}$ source. However, if depletion of the stores from one receptor leaves the other receptor's response largely unaffected, the two channels are suggested to be localized on different stores. With this approach, some investigations (e.g. on portal vein and pulmonary artery) have shown a single store containing both RyR and $\mathrm{IP}_{3} \mathrm{R}$, since depletion of the $\mathrm{Ca}^{2+}$ store by caffeine (which activates RyR) prevented $\mathrm{IP}_{3}$-mediated $\mathrm{Ca}^{2+}$ release $[31,32,39,40]$. On the other hand, other studies on pulmonary artery have suggested there may be separate stores for each receptor since depletion of the RyR-containing store did not abolish agonistevoked $\mathrm{IP}_{3}$-mediated $\mathrm{Ca}^{2+}$ release and vice versa [41]. In yet other studies (e.g. portal vein, pulmonary artery and taenia caeci), one store may express RyR and $\mathrm{IP}_{3} \mathrm{R}$ and other stores, in the same cell, only $\mathrm{IP}_{3} \mathrm{R}[11,35,42]$. This conclusion came from the finding that depletion of the $\mathrm{IP}_{3} \mathrm{R}$-containing store abolished $\mathrm{Ca}^{2+}$ release via $\mathrm{RyR}$, while depletion of the RyR-containing store did not abolish $\mathrm{Ca}^{2+}$ release via $\mathrm{IP}_{3} \mathrm{R}$. In further studies in other cell types (mesenteric artery) and in our own investigations in colonic smooth muscle [43], some stores may express both RyR and $\mathrm{IP}_{3} \mathrm{R}$ while others only RyR [30, 43]. In this case, depletion of the RyR-containing store abolished $\mathrm{Ca}^{2+}$ release via $\mathrm{IP}_{3} \mathrm{R}$, while depletion of the $\mathrm{IP}_{3} \mathrm{R}$-containing store did not abolish $\mathrm{Ca}^{2+}$ release via $\mathrm{RyR}-\mathrm{a}$ result apparently consistent with there being a store which contained RyR alone.

However, in our own later experiments examining the structure of the store [44-46] we found unexpectedly that the entire store appeared to be a single luminally-continuous entity rather than a series of separate stores. In these later experiments, to examine luminal continuity, the store was depleted at one small site in the cell by repetitively applying $\mathrm{IP}_{3}$ to a small $(10 \mu \mathrm{m})$ region under conditions preventing store refilling. Even though only a small site in the cell was activated, the store depleted throughout the cell [44]. This result suggested that $\mathrm{Ca}^{2+}$ was in free diffusional equilibrium in the store (Fig. 11.6) i.e. a luminally-continuous store. In keeping with these findings, the $\mathrm{IP}_{3}$-sensitive store also could be refilled from one small site on the cell (Fig. 11.7); a result suggesting there was a single store in which $\mathrm{Ca}^{2+}$ was able to diffuse freely throughout.

Depletion of the RyR-sensitive store at one site also depleted the entire store $[44,46]$. In this case the RyR-containing store was depleted by attaching a pipette containing ryanodine to one small site of the cell to deplete the store there. Caffeine was applied to the entire cell. If the RyR containing store comprised separate elements, depletion of one aspect of the store should not affect the $\mathrm{Ca}^{2+}$ available to be released in another area of the store. However, caffeine-evoked $\mathrm{Ca}^{2+}$ transients decreased uniformly throughout the cell $[44,46]$ suggesting that ryanodine, acting at one part of the cell, had depleted the entire store i.e. a single luminally-continuous store exists. 
a
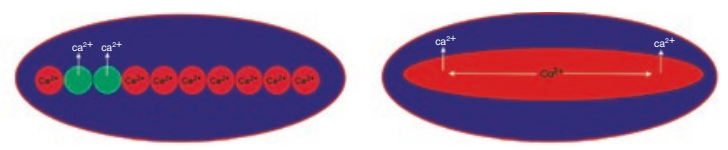

b

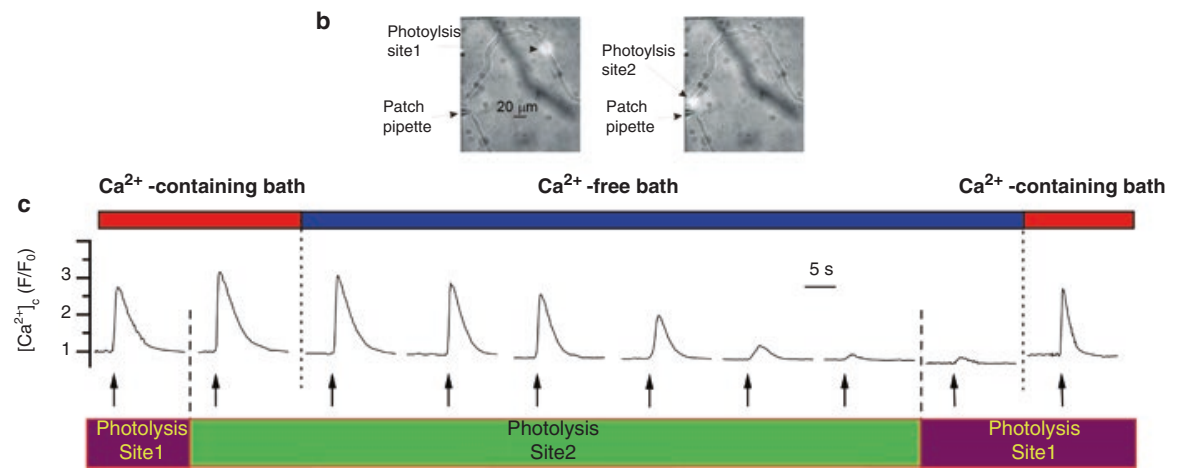

Fig. 11.6 Store luminal continuity:depletion of the $\mathrm{IP}_{3}$-sensitive $\mathrm{Ca}^{2+}$ store in a localized area depletes the entire store of $\mathrm{Ca}^{2+}$. (a) If the store was a series of luminal discontinuous elements (left) then $\mathrm{Ca}^{2+}$ release at one site would not alter the $\mathrm{Ca}^{2+}$ available for release from another. However if the store was luminally continuous, then $\mathrm{Ca}^{2+}$ release from one site would decrease the $\mathrm{Ca}^{2+}$ available for release from another site. To test this, at $-70 \mathrm{mV}$, locally-photolyzed $\mathrm{IP}_{3}(\uparrow, \mathbf{c})$ in a $10 \mu \mathrm{m}$ diameter region, (photolysis site 1; bright spot in $\mathbf{b}$ left-hand panel; see also patch electrode, left side) evoked $\mathrm{Ca}^{2+}$ transients (c). Results from photolysis site 1 are indicated by the magenta bar below the $\left[\mathrm{Ca}^{2+}\right]_{\mathrm{c}}$ trace in $\mathbf{c}$. When repositioned to photolysis site 2 (b; right hand panel) subsequent photolysis $\sim 90 \mathrm{~s}$ later produced a $\left[\mathrm{Ca}^{2+}\right]_{\mathrm{c}}$ increase (c). Photolysis site 2 is indicated by the green line below the $\left[\mathrm{Ca}^{2+}\right]_{\mathrm{c}}$ trace $(\mathbf{c})$. In a $\mathrm{Ca}^{2+}$ free solution (containing EGTA (1 $\mathrm{mM})$ and $\mathrm{MgCl}_{2}(3 \mathrm{mM})$; blue bar above the $\left[\mathrm{Ca}^{2+}\right]_{\mathrm{c}}$ trace) the $\left[\mathrm{Ca}^{2+}\right]_{\mathrm{c}}$ increase evoked by $\mathrm{IP}_{3}$ at photolysis site 2 declined in amplitude as the store was depleted of $\mathrm{Ca}^{2+}(\mathbf{c})$. When the store content had been substantially reduced at photolysis site 2 (b) (as revealed by the smaller $\mathrm{Ca}^{2+}$ transients c) $\mathrm{IP}_{3}$ was liberated by photolysis at site 1 (b). Again as at photolysis site 2 the response was now almost abolished compared to control. On restoring external $\mathrm{Ca}^{2+}$ (c, right hand side) the $\mathrm{Ca}^{2+}$ increase evoked by $\mathrm{IP}_{3}$ at photolysis site 1 was restored towards control values. These results suggest that the SR is luminally-continuous and within it $\mathrm{Ca}^{2+}$ is freely diffusible. $\left[\mathrm{Ca}^{2+}\right]_{\mathrm{c}}$ measurements were made from a $5 \mu \mathrm{m}$ diameter circle at the photolysis site. Thus when photolysis occurred at photolysis site $1\left[\mathrm{Ca}^{2+}\right]_{\mathrm{c}}$, measurements were made from a $5 \mu \mathrm{m}$ diameter circle at the photolysis site 1 . When photolysis occurred at photolysis site $2,\left[\mathrm{Ca}^{2+}\right]_{\mathrm{c}}$ measurements were made from a 5 $\mu \mathrm{m}$ diameter circle at the photolysis site 2. (b, c) These results were original published in McCarron \& Olson 2008 [44]

The question of whether there is a single store with luminal continuity or multiple stores has also been addressed in other cell types (HeLa, RBL, CHO) using a $\mathrm{Ca}^{2+}$ store-located green fluorescent protein (GFP) [47, 48]. Prolonged GFP photobleaching in a small restricted region of the cell resulted in the disappearance of fluorescence throughout store, suggesting GFP could move freely around the store to be eventually photobleached. Short periods of photobleaching were followed by a rapid restoration of fluorescence by the diffusion of GFP from sites neighbouring the photobleached region $[47,49]$. A single store with luminal continuity throughout was also suggested by the diffusion of $\mathrm{Ca}^{2+}$ in pancreatic acinar cells [8]. 


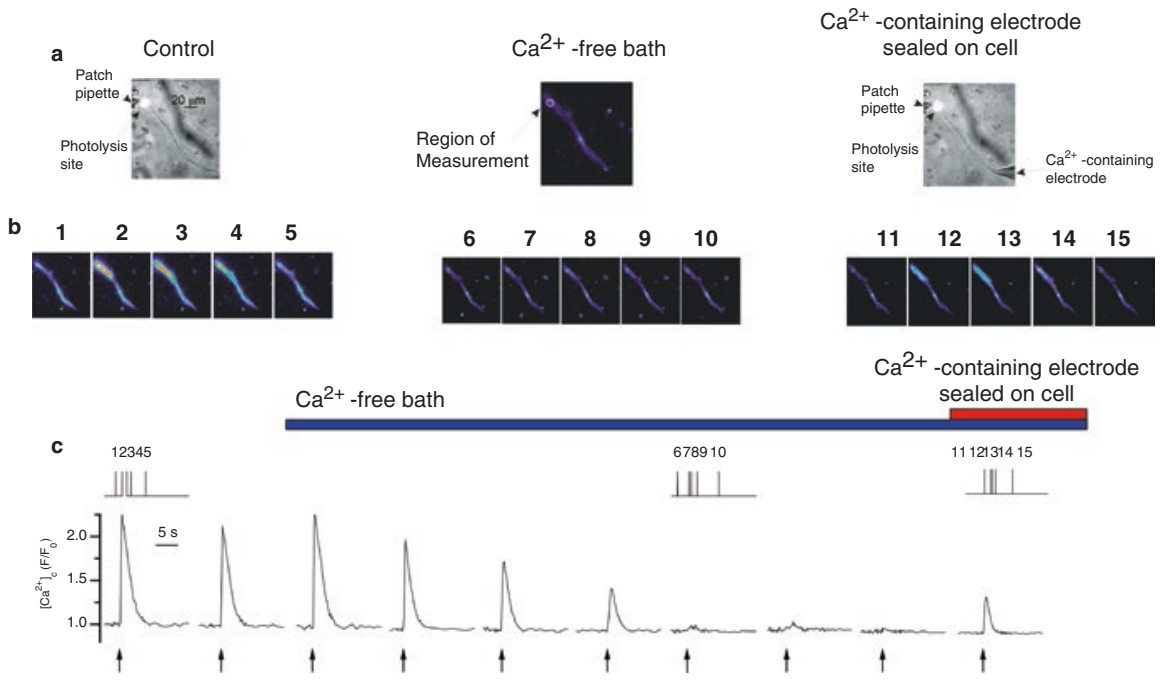

Fig. 11.7 $\mathrm{Ca}^{2+}$ can move through the SR to replenish a site previously depleted of the ion. At -70 $\mathrm{mV}$, locally-photolyzed $\mathrm{IP}_{3}(\uparrow, \mathbf{c})$ in a $10 \mu \mathrm{m}$ diameter region (bright spot in a left-hand panel; see also whole cell patch electrode (left side)) increased $\left[\mathrm{Ca}^{2+}\right]_{\mathrm{c}}(\mathbf{b}$ and $\mathbf{c})$. The $\left[\mathrm{Ca}^{2+}\right]_{\mathrm{c}}$ images $(\mathbf{b})$ are derived from the time points indicated by the corresponding numbers in $\mathrm{C}_{\mathrm{C}}\left[\mathrm{Ca}^{2+}\right]_{\mathrm{c}}$ changes in $\mathbf{b}$ are represented by colour; blue low and red high $\left[\mathrm{Ca}^{2+}\right]_{\mathrm{c}} \mathrm{A}$ second photolysis of $\mathrm{IP}_{3} \sim 60 \mathrm{~s}$ later at the same site (c) generated an approximately comparable $\left[\mathrm{Ca}^{2+}\right]_{\mathrm{c}}$ increase. In a $\mathrm{Ca}^{2+}$ free solution (containing $1 \mathrm{mM}$ EGTA and $3 \mathrm{mM} \mathrm{MgCl}{ }_{2}$; blue bar above the trace) the $\left[\mathrm{Ca}^{2+}\right]_{\mathrm{c}}$ increase evoked by $\mathrm{IP}_{3}$ declined and was abolished as the store became depleted of $\mathrm{Ca}^{2+}$. When the $\mathrm{Ca}^{2+}$ containing patch electrode was subsequently sealed onto the cell in 'cell-attached' mode (a right hand panel; c red bar) there was no measurable increase in $\left[\mathrm{Ca}^{2+}\right]_{c}$ yet the $\mathrm{Ca}^{2+}$ increase to $\mathrm{IP}_{3}$ at the photolysis region (a) was subsequently restored partially (c). This result suggests that $\mathrm{Ca}^{2+}$ had diffused through the store lumen to replenish the store. The position of the region of $\left[\mathrm{Ca}^{2+}\right]_{\mathrm{c}}$ measurement is shown as a white circle in a, center panel. These results were original published in McCarron \& Olson 2008 [44]

The $\mathrm{Ca}^{2+}$ store in the apical region was refilled with $\mathrm{Ca}^{2+}$ originating from a pipette attached to the opposite side of the cell on the basolateral membrane [see also 9]. Together, these experiments suggest the store is a luminally-continuous entity in which $\mathrm{Ca}^{2+}$ can diffuse freely throughout. How then does the appearance of multiple stores [43] occur on a single luminally-continuous store structure?

\section{Complex RyR and $\mathrm{IP}_{3} \mathrm{R}$ Regulation Characteristics and Apparent Store Configuration}

$\mathrm{IP}_{3} \mathrm{R}$ and $\mathrm{RyR}$ are each regulated by the $\mathrm{Ca}^{2+}$ concentration within the lumen of the store ('luminal $\mathrm{Ca}^{2+}$ regulation') $[4,45]$. As the luminal $\mathrm{Ca}^{2+}$ concentration increases so does the activity of the store release channels [3-6]. Conversely, the activity of 

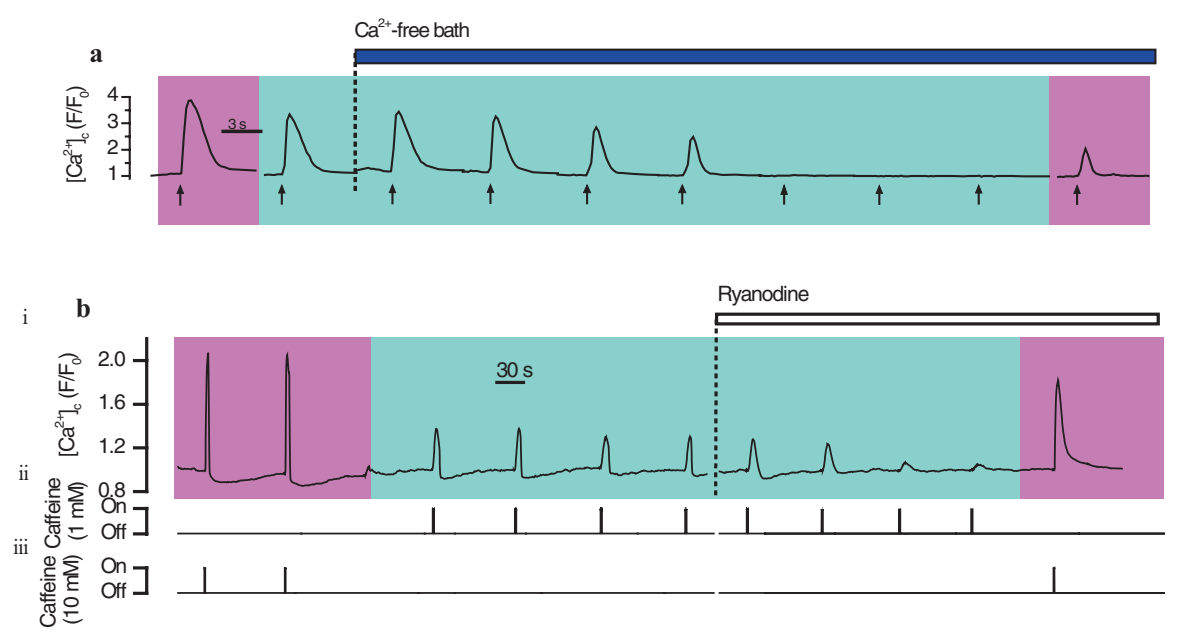

Fig. 11.8 The store may contain substantial residual $\mathrm{Ca}^{2+}$ after apparently being depleted. (a) At $-70 \mathrm{mV}$ high $\left[\mathrm{IP}_{3}\right]$ (pink; photolysed using a high lamp intensity; $\uparrow$ ) increased $\left[\mathrm{Ca}^{2+}\right]_{\mathrm{c}}$. A lower $\left[\mathrm{IP}_{3}\right]$ (light blue; $\uparrow$ ) evoked a submaximal $\left[\mathrm{Ca}^{2+}\right]_{\mathrm{c}}$ increase. In a $\mathrm{Ca}^{2+}$ free bath solution (containing $1 \mathrm{mM}$ EGTA and $3 \mathrm{mM} \mathrm{MgCl}_{2}$; dark blue bar) these increases declined then disappeared. The absence of a response to $\left[\mathrm{IP}_{3}\right]$ was not due to depletion of the store. Increasing $\left[\mathrm{IP}_{3}\right]$ (pink; right side; $\uparrow$ ) evoked further $\mathrm{Ca}^{2+}$ release. A mechanism, other than depletion of the store of $\mathrm{Ca}^{2+}$, e.g. 'luminal' regulation of $\mathrm{IP}_{3} \mathrm{R}$, may have accounted for the loss of response to $\mathrm{IP}_{3}$. The time between each $\mathrm{IP}_{3}$ challenge was approximately $1 \mathrm{~min}$. (b) Caffeine $(10 \mathrm{mM}$; iii) indicated by pink (i) evoked approximately reproducible increases in $\left[\mathrm{Ca}^{2+}\right]_{\mathrm{c}}$. (i). Caffeine $(1 \mathrm{mM}$; ii) indicated by light blue (i) evoked submaximal $\left[\mathrm{Ca}^{2+}\right]_{\mathrm{c}}$ increases (i). In ryanodine $(50 \mu \mathrm{M}$; for the duration of the unfilled bar) these increases declined to $12 \%$ of their control value (i). However, after the substantial reduction in response to submaximal caffeine $\left(1 \mathrm{mM}\right.$; ii), caffeine $\left(10 \mathrm{mM}\right.$; iii) evoked a $\left[\mathrm{Ca}^{2+}\right]_{\mathrm{c}}$ rise of $77 \%$ of its control value. The break in the record is $\sim 90 \mathrm{~s}$ in which a new data recording file was established. These results were original published in McCarron \& Olson 2008 [44]

RyR and $\mathrm{IP}_{3} \mathrm{R}$ each decrease as the store $\mathrm{Ca}^{2+}$ content declines. $\mathrm{Ca}^{2+}$ release evoked by $\mathrm{IP}_{3}$ or caffeine may substantially decline or stop as the store content falls, even when this store retains a significant residual quantity of $\mathrm{Ca}^{2+}$. To examine this possibility, a series of experiments were carried out in which the store was depleted of $\mathrm{Ca}^{2+}$ (Fig. 11.8). When the store had been 'depleted', as revealed by the inhibition of response to $\mathrm{IP}_{3}$ or caffeine, the concentration of each activator was increased and a substantial $\mathrm{Ca}^{2+}$ release occurred [44]. These experiments suggest that after apparent depletion the store retained significant quantities of $\mathrm{Ca}^{2+}$ and that residual $\mathrm{Ca}^{2+}$ is available for release with increased concentrations of $\mathrm{IP}_{3}$ or caffeine.

Interpreting the amplitude of a $\mathrm{Ca}^{2+}$ response to a single repeatedly applied concentration of either $\mathrm{IP}_{3}$ or caffeine as the store content declines is problematic as the amplitude of the response depends (1) on the position of the activator concentration on the concentration-response relationship curve and (2) the store luminal $\mathrm{Ca}^{2+}$ concentration. The absence of a response to a single concentration of $\mathrm{IP}_{3}$ or caffeine, therefore, may not reflect an absence of available $\mathrm{Ca}^{2+}$ within the store but rather 
termination of channel activity by luminal regulation of the store release channels as the store $\mathrm{Ca}^{2+}$ content declines.

Luminal regulation may explain the appearance of multiple stores when pharmacological agents and functional data are used to define store subcompartments. Indeed, we reproduced data previously interpreted as various different store arrangements in a single smooth muscle cell type. For example, after depletion of the $\mathrm{Ca}^{2+}$ stores with caffeine and ryanodine, the response to $\mathrm{IP}_{3}$ disappeared (Fig. 11.9a). This result suggest RyR and $\mathrm{IP}_{3} \mathrm{R}$ access a single $\mathrm{Ca}^{2+}$ pool. However, in the same cell type, after depletion of the $\mathrm{Ca}^{2+}$ stores with caffeine and ryanodine, when a higher concentration of $\mathrm{IP}_{3}(125 \mu \mathrm{M}$ vs. $250 \mu \mathrm{M})$ was subsequently applied, a substantial $\mathrm{Ca}^{2+}$ increase occurred (Fig. 11.9b). This result suggests $\mathrm{IP}_{3} \mathrm{R}$ accesses a different $\mathrm{Ca}^{2+}$ pool from RyR. On the other hand, after the store had been apparently depleted of $\mathrm{Ca}^{2+}$ by $\mathrm{IP}_{3}$ (at a concentration which produced a maximal response) a substantial response to caffeine persisted (Fig. 11.9c), suggesting there was a store which only contains RyR $[30,43]$. In yet other experiments, in the same cell type, when the concentration of $\mathrm{IP}_{3}$ used to deplete the store of $\mathrm{Ca}^{2+}$ was increased, no $\mathrm{Ca}^{2+}$ response to caffeine occurred i.e. the apparently separate stores for RyR disappeared (Fig. 11.9d).

Rather than there being various separate stores with different receptor arrangements, these results suggests that partial depletion of the store terminates activity of the channels by luminal channel regulation by $\left[\mathrm{Ca}^{2+}\right]$ within the store.

These results (Figs. 11.6, 11.8, 11.9) do not dispute the existence of multiple stores but suggest that care is required when interpreting results from functional data in terms of store structure. In some cells, multiple stores do exist unequivocally. Different $\mathrm{Ca}^{2+}$ concentrations have been measured in various regions of the store using recombinant aequorin [47], electron microscopic determination of $\mathrm{Ca}^{2+}$ content [50] or fluorescent indicators loaded into the cell [34], suggesting that discontinuities exist within the structures surrounding the lumen itself. The store [34] may adopt different configurations within the cell and components may even detach and reattach, so influencing the pattern and distribution of $\mathrm{Ca}^{2+}$ release channel [51]. In Purkinje neurons, for example, $\mathrm{IP}_{3} \mathrm{R}$-expressing regions may separate off from other internal store elements [52]. Store compartments exist which accumulate and release $\mathrm{Ca}^{2+}$ but are luminally-discontinuous from the bulk of the store have been observed in cultured hippocampal dendrites [53]. Life cycle stage or prior experimental conditions of the cell may influence the appearance of subcompartments. $\left[\mathrm{Ca}^{2+}\right]_{\mathrm{c}}$ increases which persisted for at least $10 \mathrm{~min}$, led to the breakdown of the $\mathrm{Ca}^{2+}$ store into subcompartments in rat basophilic leukaemia cells [49]. Store structural changes are also associated with fertilization and mitosis [54]. Fertilization leads to a reorganization of the store, measured as a slowing of the diffusion of membrane probes and luminal proteins, in sea urchin eggs [55, 56]. In mitosis, significant $\mathrm{Ca}^{2+}$ store changes also occur, which include the structure itself fragmenting into subcompartments [57, 58].

Other structures within the cell such as Golgi, mitochondria, granules and the nucleus may also contribute to $\mathrm{Ca}^{2+}$ storage [59-63] and generate subregions which appear to have various $\mathrm{Ca}^{2+}$ concentrations, especially when lipophilic $\mathrm{Ca}^{2+}$ indicators are used to image the distribution of $\left[\mathrm{Ca}^{2+}\right]$ through the cell. 
a
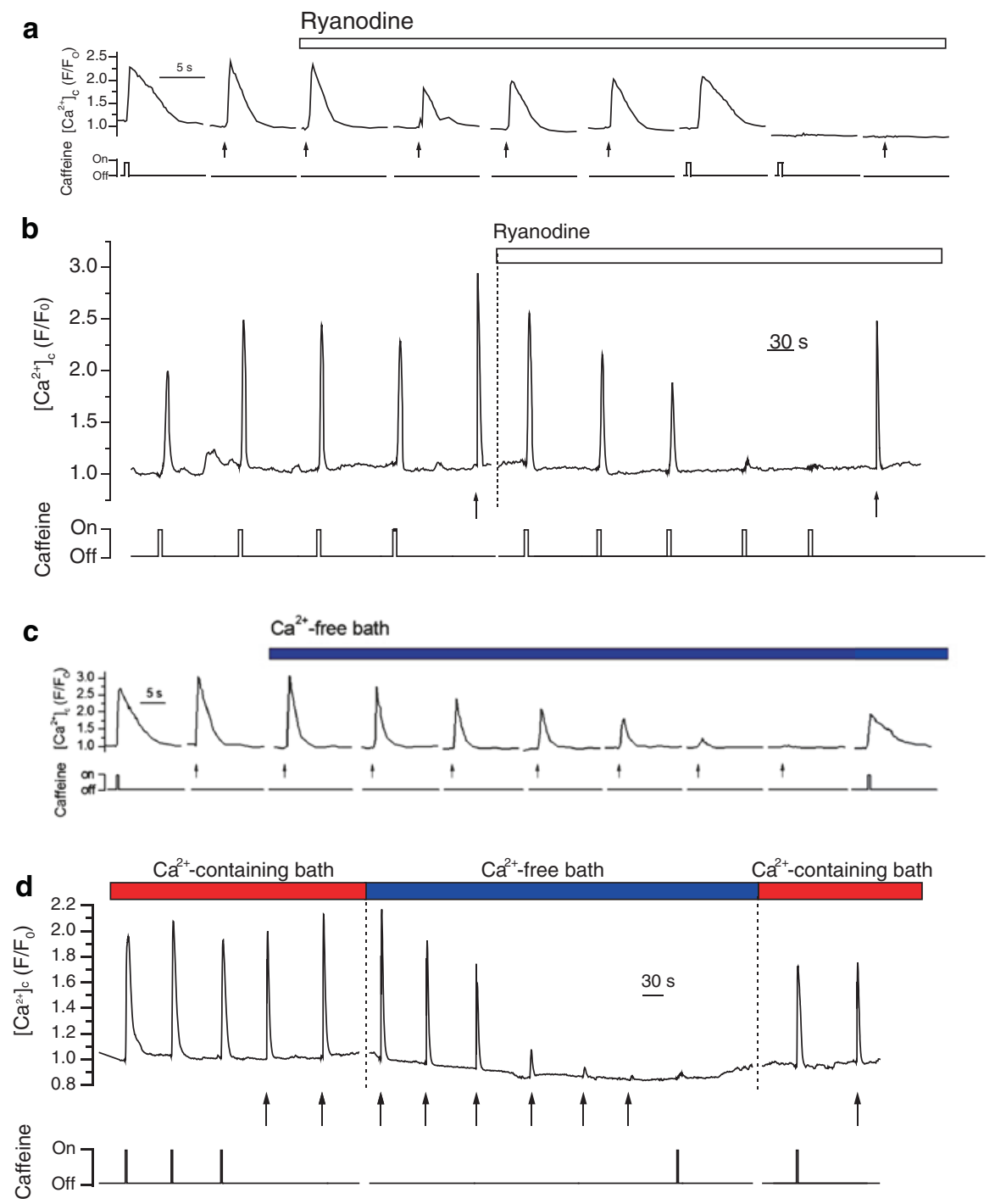

Fig. 11.9 Various apparent SR receptor arrangements. All the following experiments were performed on the same cell type (colonic smooth muscle) (a) $I P_{3} R$ and RyR access a single Ca $a^{2+}$ pool. Caffeine ( $10 \mathrm{mM}$ by pressure ejection lower trace) evoked a rise in $\mathrm{Ca}^{2+}$. $\mathrm{IP}_{3}$-evoked $\mathrm{Ca}^{2+}$ increases $(125 \mu \mathrm{M} ; \uparrow)$ were not significantly reduced by ryanodine $(50 \mu \mathrm{M}$; open bar above the trace). Activation of RyR by caffeine $(10 \mathrm{mM})$, in the continued presence of ryanodine, initially increased $\left[\mathrm{Ca}^{2+}\right]_{\mathrm{c}}$. A second application of caffeine to the same cell however some $90 \mathrm{~s}$ later, generated little increase in $\left[\mathrm{Ca}^{2+}\right]_{\mathrm{c}}$ presumably because of SR store depletion; ryanodine's effects on RyR require prior channel activation. The $\mathrm{IP}_{3}$ response was also subsequently inhibited $(\uparrow)$. Because the $\mathrm{IP}_{3}-$ evoked $\mathrm{Ca}^{2+}$ transient was not blocked by ryanodine alone (only after RyR activation with caffeine), $\mathrm{IP}_{3}$-mediated $\mathrm{Ca}^{2+}$ release did not activate RyR. $\mathrm{IP}_{3} \mathrm{R}$ and $\mathrm{RyR}$ may share a common $\mathrm{Ca}^{2+}$ store; this is depleted of $\mathrm{Ca}^{2+}$ by ryanodine, after activation of RyR by caffeine, to reduce the $\mathrm{Ca}^{2+}$ available for $\mathrm{IP}_{3}$-mediated $\mathrm{Ca}^{2+}$ release to occur. (b) $I P_{3} R$ accesses a separate $C a^{2+}$ pool from $R y R$. 


\section{Graded $\mathrm{Ca}^{2+}$ Release, $\mathrm{Ca}^{2+}$ Waves and Local $\mathrm{Ca}^{2+}$ Events from a Luminally-Continuous Store}

If the $\mathrm{Ca}^{2+}$ store in smooth muscle is indeed a single, luminally-continuous entity, how do the various physiological events (waves, graded release, local responses) previously explained with multiple separate stores occur?

$\mathrm{Ca} 2+$ waves: $\mathrm{Ca}^{2+}$ waves are the progressive movement of $\mathrm{Ca}^{2+}$ through the cell following $\mathrm{Ca}^{2+}$ release from the internal store. Using localized activation of $\mathrm{IP}_{3} \mathrm{R}$, the forward movement of the $\mathrm{Ca}^{2+}$ wave was shown to arise from CICR at the $\mathrm{IP}_{3} \mathrm{R}[13$, 16]. The decline in $\left[\mathrm{Ca}^{2+}\right]_{\mathrm{c}}$ - the back of the wave-occurred not because of depletion of separate stores but from a functional compartmentalization of the store which rendered the site of $\mathrm{IP}_{3}$-mediated $\mathrm{Ca}^{2+}$ release - and only this site-refractory to $\mathrm{IP}_{3}$ after $\mathrm{Ca}^{2+}$ release . A localized feedback deactivation of $\mathrm{IP}_{3} \mathrm{R}$ produced by an increased $\left[\mathrm{Ca}^{2+}\right]_{\mathrm{c}}$ caused the functional compartmentalization [16]. The deactivation of the $\mathrm{IP}_{3} \mathrm{R}$ was delayed in onset, compared with the time of the rise in $\left[\mathrm{Ca}^{2+}\right]_{\mathrm{c}}$ and persisted (>30 s) even when $\left[\mathrm{Ca}^{2+}\right]_{\mathrm{c}}$ had been restored to resting levels $[13,16]$. This feedback deactivation ensures the wave's progressive movement in a single direction [16].

Graded Ca2+release: There are several proposals for graded $\mathrm{IP}_{3}$-mediated $\mathrm{Ca}^{2+}$ release that do not require the presence of numerous stores with various sensitivities to $\mathrm{IP}_{3}$. Rather, at any given $\left[\mathrm{IP}_{3}\right]$ the entire $\mathrm{Ca}^{2+}$ store is activated and releases a fraction of its content, becoming partially depleted. Partial depletion may deactivate $\mathrm{Ca}^{2+}$ release $[64,65]$. Raising the $\left[\mathrm{IP}_{3}\right]$ reactivates $\mathrm{IP}_{3} \mathrm{R}$ to renew the $\mathrm{Ca}^{2+}$ release process. This proposal does not require multiple stores but a complex adaptive change in $\mathrm{IP}_{3} \mathrm{R}$ activity. Negative feedback processes operating either at the cytoplasmic or the luminal aspects of $\mathrm{IP}_{3} \mathrm{R}$ may explain the adaptive behaviour. In one proposal the binding of $\mathrm{IP}_{3}$ to $\mathrm{IP}_{3} \mathrm{R}$ may initially activate, then partially inactivate $\mathrm{IP}_{3} \mathrm{R}$ in a concentrationdependent way to produce graded $\mathrm{Ca}^{2+}$ release [66-68]. To test this proposal we examined the time course of $\mathrm{IP}_{3} \mathrm{R}$ activation at a constant $\left[\mathrm{IP}_{3}\right]$ but under conditions in which there was varying amplitude of $\mathrm{Ca}^{2+}$ release [45]. The latter was achieved by buffering the cytoplasmic $\mathrm{Ca}^{2+}$ concentration (BAPTA) or partial depletion of the store $\left(\mathrm{Ca}^{2+}\right.$ free bath solution). If $\mathrm{IP}_{3}$ inactivated $\mathrm{IP}_{3} \mathrm{R}$ to prevent release, then at

Fig. 11.9 (continued) Caffeine ( $1 \mathrm{mM}$; by pressure ejection, lower trace) evoked approximately reproducible increases in $\left[\mathrm{Ca}^{2+}\right]_{\mathrm{c}} . \mathrm{IP}_{3}(250 \mu \mathrm{M} ; \uparrow)$ also increased $\left[\mathrm{Ca}^{2+}\right]_{\mathrm{c}}$. Ryanodine $(50 \mu \mathrm{M}$; open bar) inhibited caffeine-evoked $\left[\mathrm{Ca}^{2+}\right]_{\mathrm{c}}$ increases by depletion of the SR. After the apparent depletion of caffeine-sensitive $\mathrm{Ca}^{2+}$ store, $\mathrm{IP}_{3}$-evoked a substantial $\left[\mathrm{Ca}^{2+}\right]_{\mathrm{c}}$ increase (in contrast to the results in a).(c) RyR accesses a different $C a^{2+}$ pool from $I P_{3} R$. Caffeine $(10 \mathrm{mM})$ and photolyzed $\mathrm{IP}_{3}$ $(\uparrow)$ increased $\left[\mathrm{Ca}^{2+}\right]_{\mathrm{c}}$. In a $\mathrm{Ca}^{2+}$ free solution (containing $1 \mathrm{mM} \mathrm{EGTA}$ and $3 \mathrm{mM} \mathrm{MgCl}{ }_{2} ;$ blue bar above the trace) the $\mathrm{IP}_{3}$-evoked $\mathrm{Ca}^{2+}$ transient decrease as the store was depleted of $\mathrm{Ca}^{2+}$. Following depletion of the $\mathrm{IP}_{3}$-sensitive store, caffeine evoked a substantial $\mathrm{Ca}^{2+}$ transient. (d) $R y R$ and $I P_{3} R$ access a single $\mathrm{Ca}^{2+}$ pool. Caffeine $(2 \mathrm{mM})$ and $\mathrm{IP}_{3}(125 \mu \mathrm{M})$ each evoked approximately reproducible increases in $\left[\mathrm{Ca}^{2+}\right]_{\mathrm{c}}$. Removal of external $\mathrm{Ca}^{2+}$ (and addition of $1 \mathrm{mM} \mathrm{EGTA}$ and $3 \mathrm{mM} \mathrm{MgCl}_{2}$; blue bar) reduced the $\mathrm{IP}_{3}$-evoked $\mathrm{Ca}^{2+}$ transient. Following depletion of the $\mathrm{IP}_{3}$-sensitive store, the caffeine-evoked $\left[\mathrm{Ca}^{2+}\right]_{\mathrm{c}}$ transient was inhibited (in contrast to the results in c). Reintroduction of $\mathrm{Ca}^{2+}$ (red bar) restored the $\mathrm{IP}_{3}$ - and caffeine-evoked $\mathrm{Ca}^{2+}$ transients towards control values. These results were original published in McCarron \& Olson 2008 [44] 
constant $\left[\mathrm{IP}_{3}\right]$, release should stop at approximately the same time regardless of the amplitude of the $\left[\mathrm{Ca}^{2+}\right]_{\mathrm{c}}$ rise. However, as the amplitude of the $\left[\mathrm{Ca}^{2+}\right]_{\mathrm{c}}$ rise declined (in either BAPTA or in $\mathrm{Ca}^{2+}$-free solution) the time course of release became more prolonged [45]. This result suggests that mechanisms other than $\mathrm{IP}_{3}$ inactivation of $\mathrm{IP}_{3} \mathrm{R}$ would appear responsible for terminating $\mathrm{IP}_{3}$-mediated $\mathrm{Ca}^{2+}$ release.

In another proposal, the sensitivity of $\mathrm{IP}_{3} \mathrm{R}$ to $\mathrm{IP}_{3}$ is controlled by the luminal $\left[\mathrm{Ca}^{2+}\right]$ so that as the concentration of the ion within the store lumen falls so does $\mathrm{IP}_{3} \mathrm{R}$ activity [e.g. 65, 69]. For example, decreasing the store $\left[\mathrm{Ca}^{2+}\right]$ to below $80 \%$ of the steady-state level abolished $\mathrm{IP}_{3}$-mediated $\mathrm{Ca}^{2+}$ release in rat uterine myoctes [70] [see also 65, 69]. However, it is unclear whether or not the control of $\mathrm{IP}_{3} \mathrm{R}$ activity by luminal $\mathrm{Ca}^{2+}$ operates over the store's physiological $\mathrm{Ca}^{2+}$ concentration range. The threshold for luminal regulation to begin altering the activity of $\mathrm{IP}_{3} \mathrm{R}$ is depletion of the store by $>70 \%$ of the steady-state luminal $\mathrm{Ca}^{2+}$ concentration $(500-600 \mu \mathrm{M}$; [71]) in HeLa cells. The store $\left[\mathrm{Ca}^{2+}\right]$ must also be substantially depleted in hepatocytes $\left(>45\right.$ or $95 \%$ ) [72,73] and in $\mathrm{A} 7 \mathrm{r} 5$ cells by $>70 \%$ [74] before $\mathrm{IP}_{3} \mathrm{R}$ sensitivity changes are detected. In each case, control of $\mathrm{IP}_{3} \mathrm{R}$ activity by $\mathrm{Ca}^{2+}$ binding to the luminal aspect of the receptor, is unlikely to explain 'quantal' $\mathrm{Ca}^{2+}$ release when store $\left[\mathrm{Ca}^{2+}\right]$ exceeds 55,5 , or $30 \%$ of the normal steady-state value respectively in these cells [72-74].

On the other hand, $\mathrm{IP}_{3} \mathrm{R}$ might not be controlled by luminal $\mathrm{Ca}^{2+}$ at all. Single channel $\mathrm{IP}_{3} \mathrm{R}$ activity, measured in planar lipid bilayers, increased when the $\left[\mathrm{Ca}^{2+}\right]$ at the luminal aspect of the channel declined [75]. In the latter study a luminal $\left[\mathrm{Ca}^{2+}\right]$ exceeding $1 \mathrm{mM}$ inhibited $\mathrm{IP}_{3} \mathrm{R}$ activity [75] (see also [76]). In other studies in permeabilized cells (e.g. portal vein; [18] or hepatocytes; [77]), decreases in store $\left[\mathrm{Ca}^{2+}\right]$ failed to reduce the sensitivity of $\mathrm{IP}_{3}$-mediated $\mathrm{Ca}^{2+}$ release or alter $\mathrm{Ca}^{2+}$ leak when pumps were blocked in permeabilized avian supraorbital nasal gland cells [78]. Together, these results suggest that regulation of $\mathrm{IP}_{3} \mathrm{R}$ by $\mathrm{Ca}^{2+}$ at the luminal aspect of the channel may, at best, operate over a limited range of store $\left[\mathrm{Ca}^{2+}\right]$.

Our results (Fig. 11.8) [44-46] suggest that as the store content falls $\mathrm{IP}_{3} \mathrm{R}$ become less responsive to $\mathrm{IP}_{3}$. However, rather than luminal regulation being expressed from within the store at the luminal aspect of $\mathrm{IP}_{3} \mathrm{R}$, detection of $\left[\mathrm{Ca}^{2+}\right]$ within the store may lie at the cytoplasmic aspect of $I P_{3} R$ [45]. The $\mathrm{Ca}^{2+}$ current flowing through $\mathrm{IP}_{3} \mathrm{R}$ evokes further release by a positive feedback effect of the ion at the cytoplasmic aspect of the channel, i.e. a $\mathrm{Ca}^{2+}$-dependent positive feedback loop. Reduction of the store $\mathrm{Ca}^{2+}$ content reduces the $\mathrm{Ca}^{2+}$ current flowing through $\mathrm{IP}_{3} \mathrm{R}$ and will result in a falling positive feedback at the cytoplasmic aspect of ${ }^{2} P_{3} R$ until release eventually stops. $\mathrm{Ca}^{2+}$ release is renewed by an increased $\left[\mathrm{IP}_{3}\right]$. In this case, the co-incidental activation of several neighboring $\mathrm{IP}_{3} \mathrm{Rs}$ within a cluster offsets the declining $\mathrm{IP}_{3} \mathrm{R} \mathrm{Ca}^{2+}$ current to renew positive feedback and $\mathrm{Ca}^{2+}$ release and accounts for graded $\mathrm{IP}_{3}$-mediated $\mathrm{Ca}^{2+}$ release.

Alternatively, the rise in cytoplasmic $\left[\mathrm{Ca}^{2+}\right]_{c}$, which derives from the activity of $\mathrm{IP}_{3} \mathrm{R}$, may itself inactivate the receptor [79-81]. However, if $\mathrm{Ca}^{2+}$-dependent inactivation terminated release $[16,79]$ to explain the graded $\mathrm{IP}_{3}$-mediated $\mathrm{Ca}^{2+}$ release, the $\mathrm{Ca}^{2+}$ chelator BAPTA, would have been expected to have potentiated $\mathrm{IP}_{3}$-evoked $\left[\mathrm{Ca}^{2+}\right]_{\mathrm{c}}$ increase; BAPTA decreased $\mathrm{IP}_{3}$-mediated $\mathrm{Ca}^{2+}$ release [45]. 
Localized $\underline{\mathrm{Ca} 2+\text { responses }} \mathrm{IP}_{3}$ is a rapidly diffusing messenger and $\mathrm{IP}_{3} \mathrm{R}$ are subject to positive feedback CICR on a single luminally-continuous entity, so how do highly-localized $\mathrm{Ca}^{2+}$ changes occur? In heart cells, the store is also a continuous network [82] in which $\mathrm{Ca}^{2+}$ can rapidly redistribute $[83,84]$ and positive feedback CICR occurs at RyR, yet highly localized $\mathrm{Ca}^{2+}$ release events occur. The highly localized responses arise in specialized domains formed by a junction of the store with the plasmalemma ('peripheral couplings') or the store and transverse (T)-tubules ('Dyads'). A number of proteins accrue at these specialized store domains: the L-type channel dihydropyridine receptors of the plasmalemma and T-tubules; the RyRs of store; triadin and junctin, of the store membrane; and calsequestrin (CSQ), the internal calcium binding protein [82]. The close coupling of dihydropyridine receptors and RyR provides control of $\mathrm{Ca}^{2+}$ release by $\mathrm{Ca}^{2+}$ influx. The quaternary complexes between triadin, junctin, RyR, and CSQ provides the luminal $\mathrm{Ca}^{2+}$ sensing capabilities that regulates RyR activity[85].

$\mathrm{IP}_{3}$-mediated $\mathrm{Ca}^{2+}$ signaling may also generate highly localized responses even though $\mathrm{IP}_{3}$ is a messenger that can diffuse quickly to evoke activity throughout the cell. To do this, certain receptors co-localize with $\mathrm{IP}_{3} \mathrm{R}$ to form a local signalling complex [86-89]. In cultured sympathetic neurons, although muscarinic and bradykinin receptors each stimulate phospholipase $\mathrm{C}$, only bradykinin receptors co-immunoprecipitate with, and activate, $\mathrm{IP}_{3} \mathrm{R}$ to evoke $\mathrm{Ca}^{2+}$ release [86]. The arrangement enables PLC activation by muscarinic and bradykinin receptors to evoke different cellular responses. In SH-SY5Y cells the positioning of $\mathrm{IP}_{3} \mathrm{R}$ near the plasma membrane provides a mechanism which may enable agonist activation, acting via $\mathrm{IP}_{3}$, to target specific types of cellular response i.e. by generating $\mathrm{Ca}^{2+}$ rises in specific regions of the cell [90]. The clustering of agonist-activated surface receptors in certain regions on the plasma membrane (e.g. the Escherichia coli chemotaxis receptor) may contribute further, by providing areas with increased sensitivity to extracellular stimuli [91].

Smooth muscle also assembles $\mathrm{IP}_{3} \mathrm{Ca}^{2+}$ release components into specialized $\mathrm{Ca}^{2+}$ domains [92] (Fig. 11.1). This conclusion came initially from the observation that $\mathrm{Ca}^{2+}$ waves, triggered by agonists applied to the entire cell, began consistently at the same site on successive activations in smooth muscle i.e. there appeared to be regions with preferential $\mathrm{IP}_{3}$-mediated $\mathrm{Ca}^{2+}$ release. Using centre of mass co-localization analysis of the distribution of the surface membrane receptors (for $\mathrm{ACh}$ ) and $\mathrm{IP}_{3} \mathrm{R}$, a small percentage $(\sim 10 \%)$ of sites showed co-localization. Significantly, the extent of co-localization was greatest at the $\mathrm{Ca}^{2+}$ wave initiation site. At these sites of co-localization, wave initiation may arise from a preferential delivery of $\mathrm{IP}_{3}$ from $\mathrm{mAChR} 3$ activity to particular $\mathrm{IP}_{3} \mathrm{R}$ clusters to generate faster local $\left[\mathrm{Ca}^{2+}\right]_{\mathrm{c}}$ increases. When the $\mathrm{Ca}^{2+}$ rise at the initiation site was rapidly and selectively attenuated (using photolysis of the caged $\mathrm{Ca}^{2+}$ buffer diazo-2) the $\mathrm{Ca}^{2+}$ wave shifted and initiated at a new site. Conversely, when a localized subthreshold 'priming' $\mathrm{IP}_{3}$ concentration was applied rapidly to regions distant from the initiation site, the wave initiation site shifted to the site of priming $\mathrm{IP}_{3}$ release. These results indicate that $\mathrm{Ca}^{2+}$ waves initiate where the most rapid $\mathrm{Ca}^{2+}$ change occurs at sites in which there is a structural and functional coupling of ACh receptors and $\mathrm{IP}_{3} \mathrm{R}$ (Fig. 11.1). The coupling generates junctions in which $\mathrm{IP}_{3}$ acts as a highly localized signal by being rapidly and selectively delivered to $\mathrm{IP}_{3} \mathrm{R}$. 


\section{Role of Mitochondria in Modulating $\mathrm{Ca}^{2+}$ Signals}

Away from the plasma membrane, $\mathrm{IP}_{3} \mathrm{R}$ activity in smooth muscle is also tightly regulated by mitochondria. Mitochondria have a well-developed $\mathrm{Ca}^{2+}$ uptake facility and may modulate bulk cytoplasmic $\mathrm{Ca}^{2+}$ signals [93-96] derived from $\mathrm{Ca}^{2+}$ entry and release [97]. Mitochondria also provide tight local control of $\mathrm{Ca}^{2+}$ release via $\mathrm{IP}_{3} \mathrm{R}[93,94,98]$ but $\mathrm{Ca}^{2+}$ influx via voltage-dependent $\mathrm{Ca}^{2+}$ channels or release via RyR appears to be less tightly controlled at a local level by mitochondria [93, 94].

Mitochondrial control of $\mathrm{IP}_{3} \mathrm{R}$ arises at $\mathrm{IP}_{3}$-mediated release sites. $\mathrm{IP}_{3}$-sensitive $\mathrm{Ca}^{2+}$ release initiates at discrete sites on the store that contain a few tens of $\mathrm{IP}_{3} \mathrm{R}$ from which the local increase in $\left[\mathrm{Ca}^{2+}\right]$ is called a 'puff'. $\mathrm{Ca}^{2+}$ puffs are spatially restricted events and of short duration but may interact and coalesce to generate a global release in $\mathrm{Ca}^{2+}$. Mitochondria are positioned close to $\mathrm{IP}_{3} \mathrm{R}$ and regulate activity of the channels [99]; inhibition of mitochondrial $\mathrm{Ca}^{2+}$ uptake attenuated the magnitude of $\mathrm{Ca}^{2+}$ puffs [100]. Indeed mitochondrial $\mathrm{Ca}^{2+}$ uptake was rapid enough to influence $\mathrm{Ca}^{2+}$ communication within an $\mathrm{IP}_{3} \mathrm{R}$ cluster. Mitochondrial $\mathrm{Ca}^{2+}$ uptake appears to prevent the negative feedback effect of high $\left[\mathrm{Ca}^{2+}\right]_{\mathrm{c}}$ on $\mathrm{IP}_{3} \mathrm{R}$ activity within a cluster to prolong $\mathrm{Ca}^{2+}$ release from the store [100]. As a consequence of the control at $\mathrm{IP}_{3} \mathrm{R}$, mitochondrial $\mathrm{Ca}^{2+}$ uptake exerts a pronounced effect on $\mathrm{IP}_{3}$ mediated $\mathrm{Ca}^{2+}$ release throughout the cell $[93,94,98,101]$.

Mitochondria and $\mathrm{IP}_{3} \mathrm{R}$ appear to be close, and perhaps tethered, to allow mitochondrial $\mathrm{Ca}^{2+}$ uptake, ATP supply, ROS production and or redox/antioxidant control to influence $\mathrm{IP}_{3} \mathrm{R}$ activity. Conversely, mitochondrial division (required to maintain mitochondrial population health and allow cell proliferation) involves encircling of the dividing mitochondria by a store membrane tubule at the point of mitochondrial constriction [102]. During smooth muscle proliferation $\mathrm{IP}_{3} \mathrm{R}$ expression and activity are increased [103-105] and there is a marked switch in mitochondrial phenotype from stationary to highly motile [106]. Inhibiting either $\mathrm{IP}_{3} \mathrm{R}$ activity $[104,107]$ or mitochondrial motility and division $[106,108]$ inhibits smooth muscle proliferation. The interplay between mitochondria and $\mathrm{IP}_{3} \mathrm{R}$ in smooth muscle thus presents an interesting potential therapeutic avenue by which pathological smooth muscle proliferation in vascular disease may be targeted.

Acknowledgements This work was funded by the Wellcome Trust (092292/Z/10/Z) and British Heart Foundation (PG/11/70/29086)

\section{References}

1. Westcott EB, Jackson WF. Heterogeneous function of ryanodine receptors, but not ip3 receptors, in hamster cremaster muscle feed arteries and arterioles. Am J Physiol Heart Circ Physiol. 2011;300:H1616-30.

2. McCarron JG, Chalmers S, Bradley KN, Macmillan D, Muir TC. $\mathrm{Ca}^{2+}$ microdomains in smooth muscle. Cell Calcium. 2006;40:461-93. 
3. McCarron JG, Craig JW, Bradley KN, Muir TC. Agonist-induced phasic and tonic responses in smooth muscle are mediated by $\mathrm{InsP}_{3}$. J Cell Sci. 2002;115:2207-18.

4. ZhuGe R, Tuft RA, Fogarty KE, Bellve K, Fay FS, Walsh Jr JV. The influence of sarcoplasmic reticulum $\mathrm{ca}^{2+}$ concentration on $\mathrm{Ca}^{2+}$ sparks and spontaneous transient outward currents in single smooth muscle cells. J Gen Physiol. 1999;113:215-28.

5. Nelson MT, Cheng H, Rubart M, Santana LF, Bonev AD, Knot HJ, Lederer WJ. Relaxation of arterial smooth muscle by calcium sparks. Science. 1995;270:633-7.

6. Burdyga T, Wray S. Action potential refractory period in ureter smooth muscle is set by $\mathrm{Ca}$ sparks and BK channels. Nature. 2005;436:559-62.

7. Somlyo AP. Excitation-contraction coupling and the ultrastructure of smooth muscle. Circ Res. 1985;57:497-507.

8. Mogami H, Nakano K, Tepikin AV, Petersen $\mathrm{OH}$. $\mathrm{Ca}^{2+}$ flow via tunnels in polarized cells: Recharging of apical $\mathrm{Ca}^{2+}$ stores by focal $\mathrm{Ca}^{2+}$ entry through basal membrane patch. Cell. 1997;88:49-55.

9. Park MK, Petersen $\mathrm{OH}$, Tepikin AV. The endoplasmic reticulum as one continuous $\mathrm{Ca}^{2+}$ pool: visualization of rapid $\mathrm{Ca}^{2+}$ movements and equilibration. EMBO J. 2000;19:5729-39.

10. Blaustein MP, Golovina VA, Song H, Choate J, Lencesova L, Robinson SW, Wier WG. Organization of $\mathrm{Ca}^{2+}$ stores in vascular smooth muscle: functional implications. Novartis Found Symp. 2002;246:125-37. discussion 137-41, 221-7.

11. Yamazawa T, Iino M, Endo M. Presence of functionally different compartments of the $\mathrm{Ca}^{2+}$ store in single intestinal smooth muscle cells. FEBS Lett. 1992;301:181-4.

12. Tribe RM, Borin ML, Blaustein MP. Functionally and spatially distinct $\mathrm{Ca}^{2+}$ stores are revealed in cultured vascular smooth muscle cells. Proc Natl Acad Sci U S A. 1994;91:5908-12.

13. McCarron JG, Chalmers S, MacMillan D, Olson ML. Agonist-evoked $\mathrm{Ca}^{2+}$ wave progression requires $\mathrm{Ca}^{2+}$ and $\mathrm{IP}_{3}$. J Cell Physiol. 2010;224:334-44.

14. McCarron JG, Olson ML, Currie S, Wright AJ, Anderson KI, Girkin JM. Elevations of intracellular calcium reflect normal voltage-dependent behavior, and not constitutive activity, of voltage-dependent calcium channels in gastrointestinal and vascular smooth muscle. J Gen Physiol. 2009;133:439-57.

15. Bootman M, Niggli E, Berridge M, Lipp P. Imaging the hierarchical $\mathrm{Ca}^{2+}$ signalling system in hela cells. J Physiol. 1997;499:307-14.

16. McCarron JG, MacMillan D, Bradley KN, Chalmers S, Muir TC. Origin and mechanisms of $\mathrm{Ca}^{2+}$ waves in smooth muscle as revealed by localized photolysis of caged inositol 1,4,5-trisphosphate. J Biol Chem. 2004;279:8417-27.

17. Muallem S, Pandol SJ, Beeker TG. Hormone-evoked calcium release from intracellular stores is a quantal process. J Biol Chem. 1989;264:205-12.

18. Hirose K, Iino M. Heterogeneity of channel density in inositol-1,4,5-trisphosphate-sensitive $\mathrm{Ca}^{2+}$ stores. Nature. 1994;372:791-4.

19. Shin DM, Luo X, Wilkie TM, Miller LJ, Peck AB, Humphreys-Beher MG, Muallem S. Polarized expression of $g$ protein-coupled receptors and an all-or-none discharge of $\mathrm{Ca}^{2+}$ pools at initiation sites of $\left[\mathrm{Ca}^{2+}\right]_{\mathrm{i}}$ waves in polarized exocrine cells. J Biol Chem. 2001;276:44146-56.

20. Meyer T, Stryer L. Transient calcium release induced by successive increments of inositol 1,4,5-trisphosphate. Proc Natl Acad Sci U S A. 1990;87:3841-5.

21. Bootman MD, Cheek TR, Moreton RB, Bennett DL, Berridge MJ. Smoothly graded $\mathrm{Ca}^{2+}$ release from inositol 1,4,5-trisphosphate-sensitive $\mathrm{Ca}^{2+}$ stores. J Biol Chem. 1994;269:24783-91.

22. Oldershaw KA, Nunn DL, Taylor CW. Quantal $\mathrm{Ca}^{2+}$ mobilization stimulated by inositol 1,4,5-trisphosphate in permeabilized hepatocytes. Biochem J. 1991;278:705-8.

23. Parys JB, Missiaen L, Smedt HD, Sienaert I, Casteels R. Mechanisms responsible for quantal $\mathrm{Ca}^{2+}$ release from inositol trisphosphate-sensitive calcium stores. Pflugers Arch. 1996;432:359-67. 
24. Iino M. Biphasic $\mathrm{Ca}^{2+}$ dependence of inositol 1,4,5-trisphosphate-induced $\mathrm{Ca}^{2+}$ release in smooth muscle cells of the guinea pig taenia caeci. J Gen Physiol. 1990;95:1103-22.

25. Parker I, Ivorra I. Localized all-or-none calcium liberation by inositol trisphosphate. Science. 1990;250:977-9.

26. Kasai H, Li YX, Miyashita Y. Subcellular distribution of $\mathrm{Ca}^{2+}$ release channels underlying $\mathrm{Ca}^{2+}$ waves and oscillations in exocrine pancreas. Cell. 1993;74:669-77.

27. Fogarty KE, Kidd JF, Tuft DA, Thorn P. Mechanisms underlying InsP3-evoked global $\mathrm{Ca}^{2+}$ signals in mouse pancreatic acinar cells. J Physiol. 2000;526(Pt 3):515-26.

28. Urena J, Smani T, Lopez-Barneo J. Differential functional properties of $\mathrm{Ca}^{2+}$ stores in pulmonary arterial conduit and resistance myocytes. Cell Calcium. 2004;36:525-34.

29. Noguera MA, D'Ocon MP. Different and common intracellular calcium-stores mobilized by noradrenaline and caffeine in vascular smooth muscle. Naunyn Schmiedebergs Arch Pharmacol. 1992;345:333-41.

30. Baro I, Eisner DA. Factors controlling changes in intracellular $\mathrm{Ca}^{2+}$ concentration produced by noradrenaline in rat mesenteric artery smooth muscle cells. J Physiol. 1995;482:247-58.

31. Pacaud P, Loirand G. Release of $\mathrm{Ca}^{2+}$ by noradrenaline and ATP from the same $\mathrm{Ca}^{2+}$ store sensitive to both $\mathrm{InsP}_{3}$ and $\mathrm{Ca}^{2+}$ in rat portal vein myocytes. J Physiol. 1995;484:549-55.

32. Janiak R, Wilson SM, Montague S, Hume JR. Heterogeneity of calcium stores and elementary release events in canine pulmonary arterial smooth muscle cells. Am J Physiol Cell Physiol. 2001;280:C22-33.

33. Haddock RE, Hill CE. Differential activation of ion channels by inositol 1,4,5-trisphosphate $\left(\mathrm{IP}_{3}\right)$ - and ryanodine-sensitive calcium stores in rat basilar artery vasomotion. J Physiol. 2002;545:615-27.

34. Golovina VA, Blaustein MP. Spatially and functionally distinct $\mathrm{Ca}^{2+}$ stores in sarcoplasmic and endoplasmic reticulum. Science. 1997;275:1643-8.

35. Ino M, Kobayashi T, Endo M. Use of ryanodine for functional removal of the calcium store in smooth muscle cells of the guinea-pig. Biochem Biophys Res Commun. 1988; $152: 417-22$.

36. Missiaen L, Vanoevelen J, Parys JB, Raeymaekers L, De Smedt H, Callewaert G, Erneux C, Wuytack F. $\mathrm{Ca}^{2+}$ uptake and release properties of a thapsigargin-insensitive nonmitochondrial $\mathrm{Ca}^{2+}$ store in A7r5 and 16HBe14o- cells. J Biol Chem. 2002;277:6898-902.

37. Bian JH, Ghosh TK, Wang JC, Gill DL. Identification of intracellular calcium pools. Selective modification by thapsigargin. J Biol Chem. 1991;266:8801-6.

38. Liu X, Farley JM. Depletion and refilling of acetylcholine- and caffeine-sensitive $\mathrm{Ca}^{++}$stores in tracheal myocytes. J Pharmacol Exp Ther. 1996;277:789-95.

39. Boittin FX, Macrez N, Halet G, Mironneau J. Norepinephrine-induced $\mathrm{Ca}^{2+}$ waves depend on $\mathrm{InsP}_{3}$ and ryanodine receptor activation in vascular myocytes. Am J Physiol. 1999;277:C139-51.

40. Bolton TB, Lim SP. Properties of calcium stores and transient outward currents in single smooth muscle cells of rabbit intestine. J Physiol. 1989;409:385-401.

41. Jabr RI, Toland H, Gelband CH, Wang XX, Hume JR. Prominent role of intracellular $\mathrm{ca}^{2+}$ release in hypoxic vasoconstriction of canine pulmonary artery. $\mathrm{Br} \mathrm{J}$ Pharmacol. 1997;122:21-30.

42. Iino M. Calcium dependent inositol trisphosphate-induced calcium release in the guinea-pig taenia caeci. Biochem Biophys Res Commun. 1987;142:47-52.

43. Flynn ER, Bradley KN, Muir TC, McCarron JG. Functionally separate intracellular $\mathrm{Ca}^{2+}$ stores in smooth muscle. J Biol Chem. 2001;276:36411-8.

44. McCarron JG, Olson ML. A single luminally continuous sarcoplasmic reticulum with apparently separate $\mathrm{Ca}^{2+}$ stores in smooth muscle. J Biol Chem. 2008;283:7206-18.

45. McCarron JG, Chalmers S, Muir TC. "Quantal" $\mathrm{Ca}^{2+}$ release at the cytoplasmic aspect of the ins $(1,4,5) \mathrm{p}_{3} \mathrm{r}$ channel in smooth muscle. J Cell Sci. 2008;121:86-98. 
46. Rainbow RD, Macmillan D, McCarron JG. The sarcoplasmic reticulum $\mathrm{Ca}^{2+}$ store arrangement in vascular smooth muscle. Cell Calcium. 2009;46:313-22.

47. Montero M, Alvarez J, Scheenen WJ, Rizzuto R, Meldolesi J, Pozzan T. Ca ${ }^{2+}$ homeostasis in the endoplasmic reticulum: Coexistence of high and low $\left[\mathrm{Ca}^{2+}\right]$ subcompartments in intact hela cells. J Cell Biol. 1997;139:601-11.

48. Dayel MJ, Hom EF, Verkman AS. Diffusion of green fluorescent protein in the aqueousphase lumen of endoplasmic reticulum. Biophys J. 1999;76:2843-51.

49. Subramanian K, Meyer T. Calcium-induced restructuring of nuclear envelope and endoplasmic reticulum calcium stores. Cell. 1997;89:963-71.

50. Pezzati R, Bossi M, Podini P, Meldolesi J, Grohovaz F. High-resolution calcium mapping of the endoplasmic reticulum-golgi-exocytic membrane system. Electron energy loss imaging analysis of quick frozen-freeze dried PC12 cells. Mol Biol Cell. 1997;8:1501-12.

51. Lee C, Chen LB. Dynamic behavior of endoplasmic reticulum in living cells. Cell. 1988;54:37-46.

52. Takei K, Mignery GA, Mugnaini E, Sudhof TC, De Camilli P. Inositol 1,4,5-trisphosphate receptor causes formation of ER cisternal stacks in transfected fibroblasts and in cerebellar purkinje cells. Neuron. 1994;12:327-42.

53. Bannai H, Inoue T, Nakayama T, Hattori M, Mikoshiba K. Kinesin dependent, rapid, bidirectional transport of ER sub-compartment in dendrites of hippocampal neurons. J Cell Sci. 2004; 117:163-75.

54. Boulware MJ, Marchant JS. $\mathrm{IP}_{3}$ receptor activity is differentially regulated in endoplasmic reticulum subdomains during oocyte maturation. Curr Biol. 2005;15:765-70.

55. Terasaki M, Jaffe LA. Organization of the sea urchin egg endoplasmic reticulum and its reorganization at fertilization. J Cell Biol. 1991;114:929-40.

56. Terasaki M, Jaffe LA, Hunnicutt GR, Hammer 3rd JA. Structural change of the endoplasmic reticulum during fertilization: Evidence for loss of membrane continuity using the green fluorescent protein. Dev Biol. 1996;179:320-8.

57. Koch GL, Booth C, Wooding FB. Dissociation and re-assembly of the endoplasmic reticulum in live cells. J Cell Sci. 1988;91:511-22.

58. Henson JH, Begg DA, Beaulieu SM, Fishkind DJ, Bonder EM, Terasaki M, Lebeche D, Kaminer B. A calsequestrin-like protein in the endoplasmic reticulum of the sea urchin: Localization and dynamics in the egg and first cell cycle embryo. J Cell Biol. 1989;109:149-61.

59. Missiaen L, Dode L, Vanoevelen J, Raeymaekers L, Wuytack F. Calcium in the golgi apparatus. Cell Calcium. 2007;41:405-16.

60. Dolman NJ, Tepikin AV. Calcium gradients and the golgi. Cell Calcium. 2006;40:505-12.

61. Rizzuto R, Pozzan T. Microdomains of intracellular $\mathrm{Ca}^{2+}$ : molecular determinants and functional consequences. Physiol Rev. 2006;86:369-408.

62. Pinton P, Pozzan T, Rizzuto R. The golgi apparatus is an inositol 1,4,5-trisphosphate-sensitive $\mathrm{Ca}^{2+}$ store, with functional properties distinct from those of the endoplasmic reticulum. EMBO J. 1998;17:5298-308.

63. Brini M, Murgia M, Pasti L, Picard D, Pozzan T, Rizzuto R. Nuclear $\mathrm{Ca}^{2+}$ concentration measured with specifically targeted recombinant aequorin. EMBO J. 1993;12:4813-9.

64. Missiaen L, De Smedt H, Droogmans G, Casteels R. $\mathrm{Ca}^{2+}$ release induced by inositol 1,4,5-trisphosphate is a steady-state phenomenon controlled by luminal $\mathrm{Ca}^{2+}$ in permeabilized cells. Nature. 1992;357:599-602.

65. Tanimura A, Turner RJ. Calcium release in hsy cells conforms to a steady-state mechanism involving regulation of the inositol 1,4,5-trisphosphate receptor $\mathrm{Ca}^{2+}$ channel by luminal [ca' ${ }^{2+}$. J Cell Biol. 1996;132:607-16.

66. Hajnoczky G, Thomas AP. The inositol trisphosphate calcium channel is inactivated by inositol trisphosphate. Nature. 1994;370:474-7. 
67. Marchant JS, Taylor CW. Rapid activation and partial inactivation of inositol trisphosphate receptors by inositol trisphosphate. Biochemistry. 1998;37:11524-33.

68. Wilcox RA, Strupish J, Nahorski SR. Quantal calcium release in electropermeabilized shsy5y neuroblastoma cells perfused with myo-inositol 1,4,5-trisphosphate. Cell Calcium. 1996;20:243-55.

69. Irvine RF. 'Quantal' $\mathrm{Ca}^{2+}$ release and the control of $\mathrm{Ca}^{2+}$ entry by inositol phosphates--a possible mechanism. FEBS Lett. 1990;263:5-9.

70. Shmygol A, Wray S. Modulation of agonist-induced $\mathrm{Ca}^{2+}$ release by $\mathrm{SR} \mathrm{Ca}^{2+}$ load: Direct sr and cytosolic $\mathrm{Ca}^{2+}$ measurements in rat uterine myocytes. Cell Calcium. 2005;37:215-23.

71. Barrero MJ, Montero M, Alvarez J. Dynamics of $\left[\mathrm{Ca}^{2+}\right]$ in the endoplasmic reticulum and cytoplasm of intact hela cells. A comparative study. J Biol Chem. 1997;272:27694-9.

72. Beecroft MD, Taylor CW. Incremental $\mathrm{Ca}^{2+}$ mobilization by inositol trisphosphate receptors is unlikely to be mediated by their desensitization or regulation by luminal or cytosolic $\mathrm{ca}^{2+}$. Biochem J. 1997;326:215-20.

73. Combettes L, Cheek TR, Taylor CW. Regulation of inositol trisphosphate receptors by luminal $\mathrm{Ca}^{2+}$ contributes to quantal $\mathrm{Ca}^{2+}$ mobilization. EMBO J. 1996;15:2086-93.

74. Parys JB, Missiaen L, De Smedt H, Casteels R. Loading dependence of inositol 1,4,5-trisphosphate-induced $\mathrm{Ca}^{2+}$ release in the clonal cell line a7r5. Implications for the mechanism of quantal $\mathrm{Ca}^{2+}$ release. J Biol Chem. 1993;268:25206-12.

75. Bezprozvanny I, Ehrlich BE. Inositol $(1,4,5)$-trisphosphate $\mathrm{InsP}_{3}$-gated $\mathrm{Ca}$ channels from cerebellum: conduction properties for divalent cations and regulation by intraluminal calcium. J Gen Physiol. 1994;104:821-56.

76. Thrower EC, Mobasheri H, Dargan S, Marius P, Lea EJ, Dawson AP. Interaction of luminal calcium and cytosolic atp in the control of type 1 inositol $(1,4,5)$-trisphosphate receptor channels. J Biol Chem. 2000;275:36049-55.

77. Combettes L, Claret M, Champeil P. Do submaximal InsP $\mathrm{P}_{3}$ concentrations only induce the partial discharge of permeabilized hepatocyte calcium pools because of the concomitant reduction of intraluminal $\mathrm{ca}^{2+}$ concentration? FEBS Lett. 1992;301:287-90.

78. Shuttleworth TJ. $\mathrm{Ca}^{2+}$ release from inositol trisphosphate-sensitive stores is not modulated by intraluminal $\left[\mathrm{Ca}^{2+}\right]$. J Biol Chem. 1992;267:3573-6.

79. Oancea E, Meyer T. Reversible desensitization of inositol trisphosphate-induced calcium release provides a mechanism for repetitive calcium spikes. J Biol Chem. 1996; 271:17253-60.

80. Iino M, Tsukioka M. Feedback control of inositol trisphosphate signalling by calcium. Mol Cell Endocrinol. 1994;98:141-6.

81. Adkins CE, Taylor CW. Lateral inhibition of inositol 1,4,5-trisphosphate receptors by cytosolic $\mathrm{Ca}^{2+}$. Curr Biol. 1999;9:1115-8.

82. Franzini-Armstrong C, Protasi F, Tijskens $P$. The assembly of calcium release units in cardiac muscle. Ann N Y Acad Sci. 2005;1047:76-85.

83. Wu X, Bers DM. Sarcoplasmic reticulum and nuclear envelope are one highly interconnected $\mathrm{Ca}^{2+}$ store throughout cardiac myocyte. Circ Res. 2006;99:283-91.

84. Swietach P, Spitzer KW, Vaughan-Jones RD. $\mathrm{Ca}^{2+}$-mobility in the sarcoplasmic reticulum of ventricular myocytes is low. Biophys J. 2008;95:1412-27.

85. Gyorke I, Hester N, Jones LR, Gyorke S. The role of calsequestrin, triadin, and junctin in conferring cardiac ryanodine receptor responsiveness to luminal calcium. Biophys J. 2004;86:2121-8.

86. Delmas P, Wanaverbecq N, Abogadie FC, Mistry M, Brown DA. Signaling microdomains define the specificity of receptor-mediated $\mathrm{InsP}_{3}$ pathways in neurons. Neuron. 2002;34:209-20.

87. Hur EM, Park YS, Huh YH, Yoo SH, Woo KC, Choi BH, Kim KT. Junctional membrane inositol 1,4,5-trisphosphate receptor complex coordinates sensitization of the silent EGFinduced $\mathrm{Ca}^{2+}$ signaling. J Cell Biol. 2005;169:657-67. 
88. Yuan Z, Cai T, Tian J, Ivanov AV, Giovannucci DR, Xie Z. $\mathrm{Na}^{+} / \mathrm{K}^{+}$-ATPase tethers phospholipase $\mathrm{C}$ and $\mathrm{IP}_{3}$ receptor into a calcium-regulatory complex. Mol Biol Cell. 2005; 16:4034-45.

89. Lur G, Sherwood MW, Ebisui E, Haynes L, Feske S, Sutton R, Burgoyne RD, Mikoshiba K, Petersen $\mathrm{OH}$, Tepikin AV. Inspreceptors and orai channels in pancreatic acinar cells: Co-localization and its consequences. Biochem J. 2011;436:231-9.

90. Smith IF, Wiltgen SM, Parker I. Localization of puff sites adjacent to the plasma membrane: Functional and spatial characterization of $\mathrm{Ca}^{2+}$ signaling in SH-SY5Y cells utilizing membrane-permeant caged IP ${ }_{3}$. Cell Calcium. 2009;45:65-76.

91. Thomason PA, Wolanin PM, Stock JB. Signal transduction: receptor clusters as information processing arrays. Curr Biol. 2002;12:R399-401.

92. Olson ML, Sandison ME, Chalmers S, McCarron JG. Microdomains of muscarinic acetylcholine and $\operatorname{Ins}(1,4,5) \mathrm{P}_{3}$ receptors create ' $\mathrm{Ins}(1,4,5) \mathrm{P}_{3}$ junctions' and sites of $\mathrm{Ca}^{2+}$ wave initiation in smooth muscle. J Cell Sci. 2012;125:5315-28.

93. McCarron JG, Muir TC. Mitochondrial regulation of the cytosolic $\mathrm{Ca}^{2+}$ concentration and the $\mathrm{InsP}_{3}$-sensitive $\mathrm{Ca}^{2+}$ store in guinea-pig colonic smooth muscle. J Physiol. 1999; 516:149-61.

94. Chalmers $\mathrm{S}$, McCarron JG. The mitochondrial membrane potential and $\mathrm{Ca}^{2+}$ oscillations in smooth muscle. J Cell Sci. 2008;121:75-85.

95. Kamishima T, McCarron JG. $\mathrm{Ca}^{2+}$ removal mechanisms in rat cerebral resistance size arteries. Biophys J. 1998;75:1767-73.

96. McGeown JG, McCarron JG, Drummond RM, Fay FS. Calcium-calmodulin-dependent mechanisms accelerate calcium decay in gastric myocytes from bufo marinus. J Physiol. 1998;506(Pt 1):95-107.

97. Drummond RM, Fay FS. Mitochondria contribute to $\mathrm{Ca}^{2+}$ removal in smooth muscle cells. Pflugers Arch. 1996;431:473-82.

98. Chalmers S, McCarron JG. Inhibition of mitochondrial calcium uptake rather than efflux impedes calcium release by inositol-1,4,5-trisphosphate-sensitive receptors. Cell Calcium. 2009;46:107-13.

99. Rizzuto R, Brini M, Murgia M, Pozzan T. Microdomains with high $\mathrm{Ca}^{2+}$ close to $\mathrm{IP}_{3}$-sensitive channels that are sensed by neighboring mitochondria. Science. 1993;262:744-7.

100. Olson ML, Chalmers S, McCarron JG. Mitochondrial $\mathrm{Ca}^{2+}$ uptake increases $\mathrm{Ca}^{2+}$ release from inositol 1,4,5-trisphosphate receptor clusters in smooth muscle cells. J Biol Chem. 2010;285:2040-50.

101. Chalmers S, Caldwell ST, Quin C, Prime TA, James AM, Cairns AG, Murphy MP, McCarron JG, Hartley RC. Selective uncoupling of individual mitochondria within a cell using a mitochondria-targeted photoactivated protonophore. J Am Chem Soc. 2012;134:758-61.

102. Friedman JR, Lackner LL, West M, DiBenedetto JR, Nunnari J, Voeltz GK. Er tubules mark sites of mitochondrial division. Science. 2011;334:358-62.

103. Berra-Romani R, Mazzocco-Spezzia A, Pulina MV, Golovina VA. $\mathrm{Ca}^{2+}$ handling is altered when arterial myocytes progress from a contractile to a proliferative phenotype in culture. Am J Physiol Cell Physiol. 2008;295:C779-90.

104. Wilkerson MK, Heppner TJ, Bonev AD, Nelson MT. Inositol trisphosphate receptor calcium release is required for cerebral artery smooth muscle cell proliferation. Am J Physiol Heart Circ Physiol. 2006;290:H240-7.

105. Moses S, Dreja K, Lindqvist A, Lovdahl C, Hellstrand P, Hultgardh-Nilsson A. Smooth muscle cell response to mechanical injury involves intracellular calcium release and ERK1/ERK2 phosphorylation. Exp Cell Res. 2001;269:88-96.

106. Chalmers S, Saunter C, Wilson C, Coats P, Girkin JM, McCarron JG. Mitochondrial motility and vascular smooth muscle proliferation. Arterioscler Thromb Vasc Biol. 2012; 32:3000-11. 
107. Wang Y, Chen J, Taylor CW, Hirata Y, Hagiwara H, Mikoshiba K, Toyo-oka T, Omata M, Sakaki Y. Crucial role of type 1, but not type 3, inositol 1,4,5-trisphosphate $\mathrm{ip}_{3}$ receptors in $\mathrm{IP}_{3}$-induced $\mathrm{Ca}^{2+}$ release, capacitative $\mathrm{Ca}^{2+}$ entry, and proliferation of $\mathrm{A} 7 \mathrm{r} 5$ vascular smooth muscle cells. Circ Res. 2001;88:202-9.

108. Marsboom G, Toth PT, Ryan JJ, Hong Z, Wu X, Fang YH, Thenappan T, Piao L, Zhang HJ, Pogoriler J, Chen Y, Morrow E, Weir EK, Rehman J, Archer SL. Dynamin-related protein 1-mediated mitochondrial mitotic fission permits hyperproliferation of vascular smooth muscle cells and offers a novel therapeutic target in pulmonary hypertension. Circ Res. 2012;110:1484-97.

Open Access This chapter is licensed under the terms of the Creative Commons Attribution 4.0 International License (http://creativecommons.org/licenses/by/4.0/), which permits use, sharing, adaptation, distribution and reproduction in any medium or format, as long as you give appropriate credit to the original author(s) and the source, provide a link to the Creative Commons license and indicate if changes were made.

The images or other third party material in this chapter are included in the chapter's Creative Commons license, unless indicated otherwise in a credit line to the material. If material is not included in the chapter's Creative Commons license and your intended use is not permitted by statutory regulation or exceeds the permitted use, you will need to obtain permission directly from the copyright holder. 